Healtas AL.1.504, mantapres

\title{
Forest Research in Alberta
}
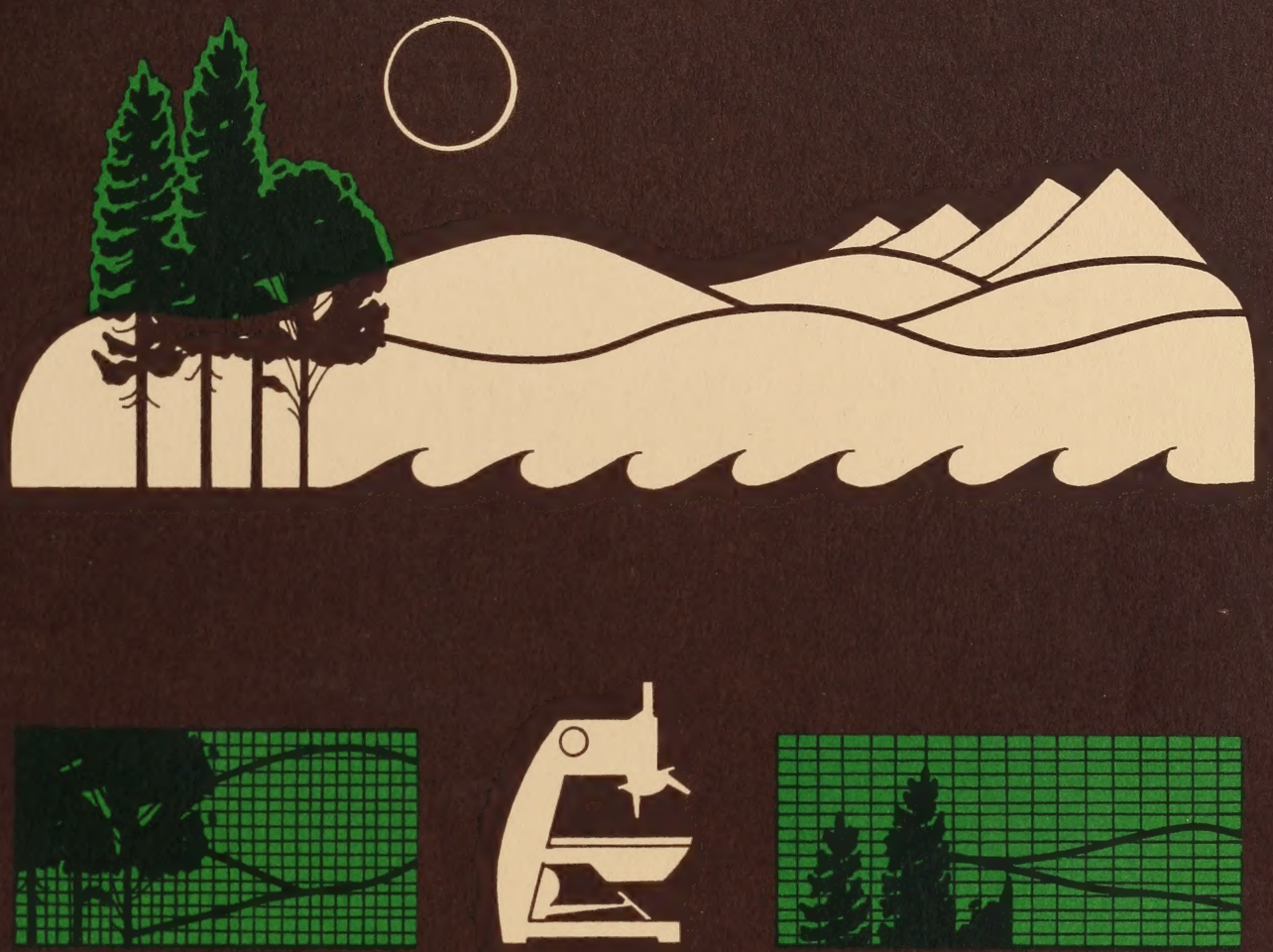

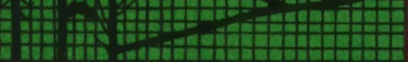
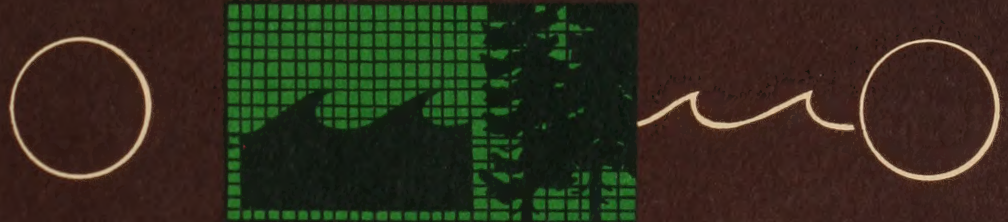

Alborta

ENERGY AND

NATURAL RESOURCES

Forest Service 
FOREST RESEARCH

IN ALBERTA

1983 
ENR No. Ref. 10 - No. 1

ISBN 0-86499-104-5

FOR ADDITIONAL COPIES, CONTACT:

Alberta Energy and Natural Resources

Forest Research Branch

215 McLeod Ave, Boville Building

Postal Bag 6343

Spruce Grove, Alberta

TOE 2CO

Phone: (403) 962-8700 


\section{TABLE OF CONTENTS}

\section{INTRODUCTION}

1.1 Importance of Forests and Forest Industry in

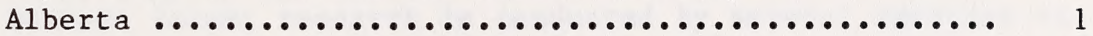

1.2 Need for New Technology $\ldots \ldots \ldots \ldots \ldots \ldots \ldots \ldots \ldots \ldots \ldots \ldots . \ldots \ldots$

2. AGENCIES ENGAGED IN FOREST RESEARCH IN ALBERTA

2.1 Alberta Forest Service $\ldots \ldots \ldots \ldots \ldots \ldots \ldots \ldots \ldots \ldots \ldots \ldots \ldots$

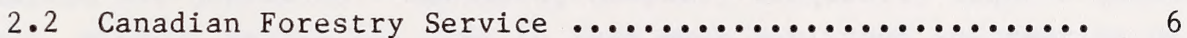

2.3 Forest Research at the University of Alberta ........ 7

2.4 Alberta Research Council ......................... 12

2.5 Research Conducted by Forest Industry .............. 13

3. DIRECTORY OF ACTIVE RESEARCH PROJECTS AND STUDIES BY VARIOUS AGENCIES

3.1 Alberta Forest Service ........................ 15

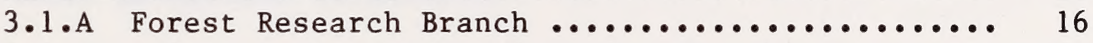

3.1.B Reforestation and Reclamation Branch ......... 36

3.1.C Forest Protection Branch .................. 45

3.1.D Forest Land Use Branch ................... 49

3.1.E Forest Products Research .................. 51

3.2 Alberta Research Council (Forest Research) ......... 58

3.3 Canadian Forestry Service, Northern Forest

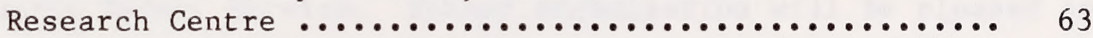

3.4 Procter \& Gamble Cellulose Ltd. .................. 125

3.5 Blue Ridge Lumber (1981) Ltd................... 130

4. APPENDIX

4.1 Staff Involved in Forestry Program at the University of Alberta ......................... 134

4.2 Graduate Students in Process at the University

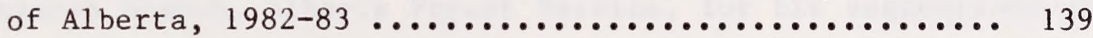

5. INDEX OF RESEARCH SUBJECT AREAS $\ldots \ldots \ldots \ldots \ldots \ldots \ldots \ldots \ldots \ldots \ldots \ldots$ 


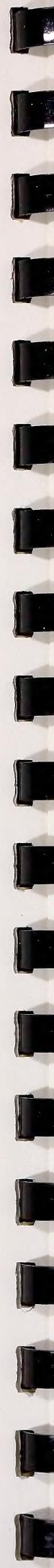




\section{PREFACE}

This publication represents the first attempt to provide information on current forest research projects and research agencies in Alberta. Because forest research is conducted by several agencies in the province, the availability of information on these research projects is not uniform. Research results are normally transmitted to forest managers in the form of publications, but preparation of publications requires considerable time, usually one year after data collection and evaluation are completed. Managers, however, frequently require answers quickly, without having the time to read much published information on a particular subject.

This directory provides names and phone numbers of researchers according to specific areas of research. It is hoped that both foresters and researchers will take this opportunity to establish personal contact and to exchange research information that will result in improved forest management in Alberta.

Lists of available publications pertaining to the research projects listed in this directory have been prepared by the Northern Forest Research Centre, Canadian Forestry Service (Information Report NOR-X-152, "Forest Research Bibliography", and annual supplements), and by the Alberta Forest Service. Either organization will be pleased to forward a copy when requested.

I would like to express my thanks to all agencies and their representatives who provided valuable information for this publication. Special thanks are extended to R. Waldron, Program Director of the Northern Forest Research Centre, Edmonton, for preparation of the Index to Forest Research in Alberta, and to Dr. S. Navratil, Research Manager, Forest Research Branch, Alberta Forest Service, for his suggestions and comments. 


\section{INTRODUCTION}

\subsection{Importance of Forests and Forest Industry in Alberta}

Alberta is the fourth largest province in Canada in terms of both productive forest land and growing stock. Approximately $60 \%$ of the total land base is forested ( $40 \mathrm{million} \mathrm{ha)} \mathrm{and} \mathrm{contains} \mathrm{an} \mathrm{estimated}$ 1.5 billion $\mathrm{m}^{3}$ of growing stock, of which $60 \%$ is coniferous forest and $40 \%$ deciduous forest. The three major coniferous species are lodgepole pine, jack pine and white spruce.

The current (1983-1984) annual softwood harvest is 7.1 million $\mathrm{m}^{3}$ softwood, and 0.2 million $\mathrm{m}^{3}$ hardwood, representing only $28 \%$ of the annual allowable cut of 26 million $\mathrm{m}^{3}$ for softwoods and hardwoods. Alberta therefore has great potential for increased forest harvesting and for developing a major forest industry.

Approximately 18,000 people in Alberta's work force are directly or indirectly employed by the forest industry. Salaries and wages paid to individuals directly employed in the forest industry, amounted to $\$ 221$ million in 1981 .

There were 441 primary wood-using firms in the province in 1983. Twenty-six communities were totally dependent upon the forest industry for their existence and another 12 communities were heavily dependent.

The value of shipments for the forest industry exceeded 991 million in 1981, accounting for $9.6 \%$ of Alberta's total and ranked third after the food and beverage industry and the petroleum and coal products industry.

While Alberta's forest industry is relatively young in comparison with the forest industries of British Columbia, Ontario and Quebec, it has the potential to develop into one of the major producers of forest products in Canada. Alberta is the only province in Canada 
having a large surplus of uncommitted accessible standing timber. Last, but certainly not of least importance, is the fact that Alberta has the highest success in reforestation of harvested forest land.

The value of forests is not limited only to their use by the forest industry. Forests maintain many other useful functions such as controlling and stabilizing stream flow and preventing flooding. They provide food and shelter for wildlife, form a backdrop for a variety of recreational activities and serve as a major producer of oxygen.

Forests are a renewable resource, whereas petroleum, coal and metallic minerals are not. Part of Alberta's future lies with the intelligent management and protection of its forests. Forest research provides the necessary techniques and background to carry out those important tasks.

\subsection{Need for New Technology}

The most important element of forest research, in addition to well-trained staff and adequate funds, is time. Forest trees in Alberta's climatic conditions require 60-80 years to mature versus the one year needed for agricultural crops. Therefore, forest research should be pursued vigorously now, to obtain answers not only to current problems but also for those that will require solutions 10 years from now.

Although there is a large surplus of uncommitted timber in Alberta at present, forest land is continuously being lost to other uses such as agriculture, wilderness areas and recreation. Also, because of unfavorable weather conditions, large areas of forests are lost to fire. Furthermore, a large proportion of surplus timber in the province is poplar, which has limited use unless new technology is developed and applied.

Three major thrusts in current and future research may offset losses from forest land and help maintain or exceed current wood production: a) development of more effective forest protection techniques against fire and pests; b) development and application of more intensive forest management techniques; and c) better utilization of coniferous resources and development and application of new techniques for poplar utilization. 
Development of More Effective Forest Protection Techniques against Fire and Pests

Forest fires destroyed large forest areas (2.5 million ha) from 1980 to 1982. There is a need for better forecasting of prolonged drought conditions and faster, more accurate detection systems in fire protection. A continuous search should be maintained for the development of more effective fire retardants and fire-suppression techniques.

The mountain pine beetle represents the greatest danger to lodgepole pine forests. Environmentally safe and effective control methods are needed, such as pheromones and hyperparasites. There are also several fungi that attack and kill forest trees at different stages for which the best possible solution is to develop resistant strains of trees. This of course requires long-term research.

\section{Development and Application of More Intensive Forest Management}

\section{Techniques}

It has been proven in Scandinavia, which has similar climatic conditions to Alberta's, that the application of intensive forest management techniques can increase forest yield by approximately $100 \%$. Some current and previous research conducted in Alberta appears to support similar growth response in the province's forests. In order to assess forest response to intensive management, both short- and longterm research studies should be initiated and maintained for many decades. Such studies should include site classification, improvement of nursery techniques, reforestation prescriptions based on site classification, postplanting care of plantations, thinning, fertilization, genetics, stand development of managed stands and management of peatland. In addition severely disturbed industrial sites must be reclaimed to ensure that the productivity and appearance of land are restored.

Better Utilization of Coniferous Resources and Development and Application of New Technology for Poplars

One way to extend the wood supply is to learn how to use it more efficiently. Research is needed to develop less wasteful harvesting techniques and new ways to protect wood in use. 
Studies on the economics of wood processing can provide much useful information for sawmill operators. Other possible studies could cover a spectrum from basic research on wood properties and characteristics to practical improvements in manufacturing techniques. Some emphasis should be directed toward converting currently unused wastewood into marketable products. Special emphasis should be placed on the development and testing of aspen forest products, including lumber, flakeboard and pulping, with special reference to chemi-thermomechanical pulping (CTMP). This process offers an excellent opportunity for the use of poplar mixed with conifers to produce pulp of a quality that may be competitive with bleached Kraft pulp. 


\section{AGENCIES ENGAGED IN FOREST RESEARCH IN ALBERTA}

\subsection{Alberta Forest Service}

Historically, both the Alberta Forest Service (AFS) and private forest industry have been dependent upon forest research conducted by the Canadian Forestry Service or its predecessors.

The government of Alberta has recognized however, that research results are lacking in many areas which may hinder progress toward improved forest management. Therefore, the Alberta Forest Service initiated some mission-oriented research programs in the mid-1970s and a Forest Research Branch was created in 1980. The Alberta Forest Service has two major research-oriented programs: a) forest land management research; and b) forest products research.

The forest land management related research is conducted mainly by the Forest Research and Reforestation and Reclamation branches. Minor programs are carried out by the Timber Management, Forest Protection and Forest Land Use branches. The Forest Service employs three methods to accomplish forest research:

a) in-house, conducting its own research programs

b) contracting research to other research agencies

c) providing grant funds to other research agencies.

Forest products research is approved by a management committee consisting of three members, one representative each, from the Alberta Forest Service, Alberta Economic Development and the Alberta Research Council. Funding for this type of program is obtained from the Alberta Forest Service budget. Details related to research programs are provided under the Alberta Research Council since a major portion of forest products research is contracted out to the Research Council. 
There are 11 currently active projects in the area of forest land management research which has the following budget and staff:

Budget $\$ 2,200,700$

$\begin{array}{lr}\text { Staff } & \\ \text { Professional } & 14 \\ \text { Technical } & 5 \\ \text { Administrative support } & \frac{5}{24} \\ \text { TOTAL } & \end{array}$

\subsection{Canadian Forestry Service}

Most of Canada's forests are on provincial lands where the responsibility for management rests with the provinces. The federal government however, plays an important supportive role in the forestry sector regionally, nationally and internationally through the Canadian Forestry Service (CFS). The most well-known CFS activity is the undertaking of in-house research and development programs which are carried out at two national forest institutes and six regional forest research centres. In addition, CFS provides annual grants ( $\$ 1.3$ million) in support of research conducted by the forestry departments at six Canadian universities; and approximately $\$ 920,000$ are available for carrying out research and development projects under contract with CFS. Funding for applied research and technology transfer will also be made available to contractors through federal-provincial forestry agreements currently being negotiated with all provinces. The main thrust of the forestry agreements will be to provide matching and incentive operational funds in support of provincial forest renewal and stand tending programs.

The Northern Forest Research Centre, located in Edmonton, carries out forest research in Alberta, Saskatchewan, Manitoba and the Northwest Territories. In addition, suboffices have been established in Prince Albert and Winnipeg to ensure effective liaison and technology transfer in Saskatchewan and Manitoba. Until the mid-1970s the Northern Forest Research Centre (NoFRC) was almost the sole contributor to forest research in Alberta. A memorandum of understanding concerning the coordination of forest research was signed in May, 1982 between the minister of Environment Canada and the minister of the Alberta Department of Energy and Natural Resources. This agreement states that "the 
Canadian Forestry Service will develop its capability in forest protection research to address major problems in fire, insects and diseases, effects of toxic substances on forest vegetation and soils, and conduct mainly basic research and methodology development studies related to watershed management, forest renewal, forest productivity, forest ecology relationships, resource economics, remote sensing and computer applications."

The research is organized under three programs - resources, protection and environment - on a project basis; each project consists of several studies. In 1982 to 1983 there were 17 projects with the following budget and staff:

Budget

$$
\$ 6,000,000
$$

\section{Staff}

$\begin{array}{lr}\text { Professional and scientific } & 57 \\ \text { Technical (including summer students) } & 59 \\ \text { Administrative support } & \underline{25} \\ \text { TOTAL } & 141\end{array}$

A program manager for, regional development has recently been hired to assume responsibility for the development and implementation of federal-provincial forestry agreements.

\subsection{Forest Research at the University of Alberta}

The forestry program at the University of Alberta is integrated within the Faculty of Agriculture and Forestry so activities are supported by staff representing a broad range of interests. Some forestry-related work is also done outside the faculty.

The staff list in Appendix 4.1 gives the areas of specialization for those members most closely associated with the forestry program, along with other university staff working in this field. Through a combination of full-time staff, associate academic staff appointments, sessional lecturers and research associates, a strong and diverse program is emerging. 
There are approximately 50 graduate students currently studying in various fields within departments of the Faculty of Agriculture and Forestry. A list of the graduate students and thesis topics is given in Appendix 4.2.

Some of the highlights which warrant specific mention include the following. The list is not inclusive of all the work in process.

\section{Forest Genetics}

A team of research associates and technicians is being built up under the direction of $\mathrm{Dr}$. Bruce Dancik, who has also developed strong ties with the Genetics Department in the Faculty of Science. Since January, 1983, special funding has been available from a Natural Sciences and Engineering Research Council (NSERC) development grant for a project that involves Drs. A.K. Hellum, K.0. Higginbotham, M.M. Micko and members of the Genetics and Entomology departments and outside agencies. Dr. L.Z. Florence was hired as an assistant professor under a position funded by NSERC and the Alberta Forest Service to conduct a research project related to the evolution and population structure of lodgepole pine with the previously mentioned team.

Additional studies include efforts to characterize the genetics of forest trees in relation to microhabitats both above and below the soil surface by analyses of biomass, soil chemical-physical variation, associated $\mathrm{N}_{2}$-fixing bacteria and seedling responses to varying temperatures.

\section{Forest Tree Seed Biology}

Dr. Hellum spent six months at the Canadian Forest Tree Seed Centre in Thailand, sponsored by the Canadian International Development Agency. The work centres on seed collection and storage techniques and studies of tree seed physiology. The relationship between seed germination and seed maturity of selected native trees and shrubs in Alberta is under study. 
Dr. J.R. Butler is developing a centre for studies in wildland recreation planning, management and interpretive programming. Expanded study opportunities are being created co-operatively with the departments of Recreation Administration and Geography and through employment of sessional lecturers. Graduate studies and research projects are being conducted in a number of fields which include studies of crosscountry skiers and back-country users in Kananaskis, trout fishermen along the Ram River and wildlife feeding conflicts in the national parks.

\section{Ecophysiology}

Current research efforts in ecophysiology include environments, the biology of reclaiming mined areas in commercial forests, and prediction of growth based on biophysical parameters. Dr. K.O. Higginbotham and graduate students are also beginning work on nutrient cycling and mycorrhizal relationships.

\section{Forest Management}

Dr. J.F. Beck and Prof. B.L. Phillips are developing a centre for the study of computer applications to timber resource allocation. Recent studies include evaluation of the Timber Resources Allocation Method (RAM) for use in Alberta, a number of timber supply analyses, yield prediction and evaluation of intensive management alternatives. Work is continuing on acquiring additional harvest scheduling models which will be evaluated for use in specific situations.

Forest Measurement, Modelling and Biometrics

Drs. J.D. Heidt and S.J. Titus for the past several years have been involved in the development of computer-based stand growth models for predicting changes in tree and stand parameters over time. The initial work, concerned with the growth and development of natural stands of trembling aspen, has been expanded to include examination of spruce, pine and mixedwood stands in Alberta. Direct byproducts of this 
research have been studies of growth differences in aspen clones, estimation of site index and development of methods for prediction of individual tree mortality. Related studies in Bayesian sampling, continuous forest inventory and volume estimation are also in process. An evaluation of interpretation accuracy of medium-scale aerial photography for forest inventory was also conducted.

\section{Fire Science and Management}

Several studies by graduate students under the direction of Dr. P.M. Woodard and Prof. P.J. Murphy have been accomplished or are currently underway. Co-operative studies with the Alberta Fish and Wildlife Division pertaining to the effects of fire on habitats used by Rocky Mountain bighorn sheep, sharp-tailed grouse, moose, elk and bison have been completed; currently, studies involve the relationship between fire and furbearers in Alberta. In addition, there is co-operation with the Canadian Forestry Service and Parks Canada on fuel and fire behavior studies at Elk Island and Jasper national parks. A study of fuel and fire behavior in Kananaskis Provincial Park was completed last fall.

\section{Wood Science}

A growing research unit in wood science under the direction of Dr. Micko is located in the Department of Agricultural Engineering. Studies of physical properties of wood, such as specific gravity and fibre quality, are under way with the assistance of two research associates (postdoctoral fellows). A co-operative agreement with the Alberta Research Council was completed recently to enable studies in wood chemistry to be done using lab facilities in the new AgricultureForestry Centre. In addition, a new building for a forest products laboratory has been acquired at the university farm which is being set up with the University of Alberta and the Alberta Research Council for forest products testing.

\section{Wildlife Productivity}

Dr. R.J. Hudson, Animal Science, is directing a number of graduate students in projects dealing with game ranching on marginal lands in Alberta, the Northwest Territories and Kenya. Of particular 
relevance is work on the use of aspen as a forage species rather than for wood fibre. The possibility for developing game ranching techniques is promising. Species under study include moose, wapiti, caribou, hippopotamus and Kenyan ungulates.

\section{Forest Soils}

Interesting studies by Drs. F.D. Cook and F.V. McHardy involve soil micro-organisms including mycorrhizae. A graduate student working with them and Dr. Dancik has been investigating moss/micro-organism nitrogen-fixing complexes. Dr. D.J. Pluth is investigating greenhouse performance of white spruce on various soils reflective of edaphic ecotypes. Peatland sites are being studied in a co-operative project with Dr. J. Toth of the Department of Geology.

\section{Forest Pathology}

Studies of pathogens and specific processes leading to mortality are the subject of co-operative studies involving Dr. Peter Blenis in Plant Science, Dr. W. Ayer in Chemistry, Dr. Hellum in Forest Science and especially Dr. Yasu Hiratsuka of the Canadian Forestry Service, an associate academic staff member. Studies are focusing on western gall rust, Armillaria root rot and blue-stain fungi associated with Dutch elm disease. Dr. Eiji Nagasawa of the Tottori Mycological Institute in Japan spent six months as a visiting scientist, Studying macrofungi in Alberta forests with Dr. Hiratsuka. Dr. M.A. Pickard, Department of Microbiology, is investigating antifungal substances from Scytalidium species active against Endocronartium harknesii, western gall rust.

\section{$\underline{\text { Reclamation }}$}

Various studies and projects in the departments of Soil Science, Plant Science and Forest Science relate to reclamation of disturbed land. Dr. R.L. Rothwell is working with Dr. David Walker on establishment of grasses. Dr. W.B. McGill of the Department of Soil Science is studying processes of soil amelioration. R.H. Hillson is continuing to direct studies of vegetative propagation techniques for native woody plant species. Dr. R.L. Rothwell and graduate students are continuing 
studies of wetland hydrology basic to assessment of potential productivity.

\section{Forest Economics}

Drs. M.R. Carroll and W.E. Phillips have been working on an Alberta wood chip utilization study which will be completed in 1983 . W.E. Phillips has been collaborating with graduate students on several projects including economic analyses of fish and wildlife recreational activities in Alberta and forest land-use trade-offs in Alberta. Cooperative studies involving Dr. J.A. Beck are being developed.

\section{Range Management}

Dr. A.W. Bailey, Plant Science, and his graduate students and technicians are studying several means of improving the forage productivity of grass and forested rangeland. Major emphases are on the effects of fire, grazing and herbicides on these ecosystems.

\section{Forest Entomology}

Dr. W.G. Evans is studying host and habitat selection in insects, including forest species associated with trees and litter.

\subsection{Alberta Research Council}

Under the direction of a management committee comprising representatives from Alberta Forest Service, Alberta Economic Development and Alberta Research Council, the Research Council carries out under contract a forest products research program which is approved annually by the committee and funded from the Alberta Forest Service budget.

The forest products research program commenced its first full year of operation in 1982-83 with a budget of $\$ 900,000$. Of this, $\$ 525,000$ is granted directly to the Alberta Research Council while the remainder is directed toward strategic studies and to further expand the forest industries. Most of the products listed in the directory have 
been contracted to consultants in the private sector and this practice will continue until the Alberta Research Council has the capability of conducting research and development work in-house.

The priorities of the program are to assist the existing forest products industry in increasing productivity, to improve resource utilization and to develop new products and processes for increased poplar utilization.

\subsection{Research Conducted by Forest Industry}

Traditionally, forest research needs of the forest industry were carried out by the Canadian Forestry Service in a co-operative arrangement. The description of various research studies and the publication of research results were the responsibility of the Canadian Forestry Service. Procter and Gamble Cellulose Ltd. was the first Forest Management Agreement (FMA) holder to recruit a research forester. Since that time, a considerable number of studies were initiated and maintained by the company, including research into various reforestation techniques, site classification, provenance studies, genetics, application of herbicides and fertilization.

Similar studies on a smaller scale were established by other FMA holders such as St. Regis (Alberta) Ltd. and Blue Ridge Lumber (1981) Ltd. British Columbia Forest Products Ltd. commenced an ambitious site classification program for the eastern half of the Berland FMA in 1981, before any harvesting activities began. There is a major co-operative genetics program which has been in existence between the major FMA holders and Alberta Forest Service since 1976. Although the forest industry's involvement in this program is mainly operational, there is some element of research present. 
3. DIRECTORY OF ACTIVE RESEARCH PROJECTS

AND STUDIES BY VARIOUS AGENCIES

3.1 Alberta Forest Service (AFS)

A. Forest Research Branch Projects

B. Reforestation and Reclamation Branch Projects

C. Forest Protection Branch Projects

D. Forest Land Use Branch Projects

E. Forest Products Research Projects 


\subsection{A.1 Forest Research Branch (AFS) Project}

PROJECT :

Alberta Forest Development Research Trust Fund

RESPONSIBILITY CENTRE:

Forest Research Branch, Alberta Forest Service

CO-OPERATORS :

$$
\begin{aligned}
& \text { University of Alberta } \\
& \text { University of Calgary } \\
& \text { Forest industry } \\
& \text { Various AFS branches }
\end{aligned}
$$

SOURCES OF FUNDING:

Government of Alberta

Forest industry

DURATION :

Long-term

Individual studies have short-term duration (one to five years).

MAJOR OBJECTIVES :

1. To provide funding for graduate studies in the field of forest science and related areas, thus ensuring a reservoir of research talent and expertise for Alberta.

2. To support basic and frontier forest research in Alberta.

3. To encourage centres of excellence in forest science within Alberta.

BENEFITS ON COMPLETION:

Basic, fundamental research into forest science issues in Alberta is addressed now to ensure that the foundations are laid for applied forestry research in the future. 
Innovative solutions to practical problems in the future will be pursued by an adequate reservoir of trained researchers familiar with Alberta conditions.

HIGHLIGHTS OF ACCOMPLISHMENTS TO DATE:

Forty studies have been funded since 1975 under this project.

Five continuing studies were renewed in fiscal year 1982/83 and five new ones initiated. A list of individual studies in progress is attached.

CONTACT :

$\begin{array}{ll}\text { Name: } & \text { J. Soos } \\ \text { Address: } & \text { Forest Research Branch } \\ & \text { Alberta Forest Service } \\ & 215 \text { McLeod Avenue } \\ & \text { Postal Bag } 6343 \\ & \text { Spruce Grove, Alberta } \\ & \text { TOE 2C0 }\end{array}$

Phone: (403) 962-8700

FINANCES :
1982/83 expenditure
$\$ 150,000$
Total funds spent to date
$\$ 705,000$
Projected expenditure for next five years
$\$ 650,000$

LIST OF STUDIES IN CURRENT FISCAL YEAR

\section{Title}

1. Economic consequences of forest land losses to non-timber uses in Alberta with particular reference to agriculture.

\section{Objectives}

To identify and describe recent forest land use changes for timber-related uses toward other 1 and uses with particular emphasis on agriculture and to develop economic techniques for the evaluation of this change.

\section{Investigator}

B.L. Phillips, U. of Alberta 
Title

2. Sawmill scale and residue utilization.

3. Variation of anatomical and physcial properties of aspen in Alberta.

4. Isolation and characterization of antifungal substance(s) produced by Scytalidium uredinicola, a hyperparasite of Endocronartium harknessii, western gall rust.

5. Variation of anatomical and physical properties of white spruce and lodgepole pine grown in Alberta.
Objectives

Investigator

To prepare a simulation model for the B.L. Phillips, $\mathrm{U}$. of Alberta Alberta sawmill industry to determine profitability of residue utilization, and how profitability relates to size and location of industrial sawmills.

To describe the variation of specific M.M. Micko, U. of Alberta gravity and fibre length in naturally occuring clones of aspen in Alberta.

To demonstrate ability M.A. Pickard, of compound(s) proU. of Alberta duced by $\underline{\text { s. uredini- }}$ cola to inhibit the germination of $\underline{E}$. harknessii spores in vitro; to isolate and purify the active compounds; to test effectiveness of these compounds as a possible means of biological control.

To characterize the natural variation of M.M. Micko, wood properties in terms of specific gravity and fibre length. 
Title

6. Determination of a chemical and biological assay for blue-stain fungi.

7. Pathological and phytochemical studies of Armillaria root rot in intensively-managed young coniferous forests of Alberta.

8. Correlation of global and net radiation with evapotranspiration on a forested wetland site in northern Alberta.

\section{Objectives}

To develop biological or phytochemical tests for assaying inhibition of water uptake caused by stain fungi.

To determine the relationship between pathogen distribution and disease distribution in selected sites.

To study the pathogenesis of disease and weakening predisposition phenomenon.

To identify biologically active metabolites produced by the pathogen and to test reaction to the toxins of various provenances of lodgepole pine and white spruce.

To establish a set of empirical relationships between total global shortwave radiation and evapotranspiration, and net radiation and evapotranspiration for a forested wetland site.
Investigator

W.A. Ayer, $\mathrm{U}$. of Alberta

Y. Hiratsuka, CFS, NoFRC

Y. Hiratsuka, CFS, NoFRC

W.A. Ayer,

$\mathrm{U}$. of Alberta
R.L. Rothwe11, $\mathrm{U}$. of Alberta 
$\underline{\text { Tit le }}$

Objectives

To use these relationships and attendant data as a basis for evaluation of existing methods for estimating evaporation from wetlands, and/or to develop a method based on readily available climatic data.

9. Field and greenhouse performance of white spruce edaphic ecotypes.

10. Flora of Alberta.
To determine the survival and growth of white spruce populations from soils of differing $\mathrm{Ca}$ concentrations grown in high-Ca and low-Ca soil media.

Completion of an upto-date second edition of "Flora in Alberta" which fully represents current knowledge.
D.J. Pluth/

B.P. Dancik, U. of Alberta
J. Packer, U. of Alberta 


\subsection{A.2 Forest Research Branch (AFS) Project}

PROJECT :

Contract research

RESPONSIBILITY CENTRE:

Forest Research Branch, Alberta Forest Service

CO-OPERATORS :

University of Alberta

University of Calgary

Private consultants

Alberta Research Council

Canadian Forestry Service

SOURCES OF FUNDING:

Government of Alberta

Alberta Heritage Savings Trust Fund

DURATION :

Long-term continuing program.

Individual studies: one to three years

MAJOR OBJECTIVES :

To assist research managers in the execution of their programs.

Specific reasons for entering into a research contract are:

1. Short-term assignments that require specialized professional services; however, continued employment after the completion of the assignment is not justified.

2. Need for a specific body of expertise which is not available within the government. 
3. Need for access to specialized facilities which are not available within the government. This may be on a "onetime" or "occasional use" basis that does not warrant their construction by the government.

4. Routine analysis of samples requiring established techniques which can be performed more economically in private laboratories.

BENEFITS ON COMPLETION:

Research contracts increase the productivity of research managers by assigning study components to a contractor for execution. In this way several activities within a program can proceed concurrently.

In addition, contracts allow access to large-scale, multi-agency or government/industry research programs. Co-operative, multidisciplinary programs have a much higher information return than the sum of individual, unco-ordinated projects costing the same amount.

HIGHLIGHTS OF ACCOMPLISHMENTS TO DATE:

A total of 58 research contracts was authorized since 1975. In the $1982 / 83$ fiscal year 14 contracts including various research studies and services were approved. Four final reports are expected at the end of the current fiscal year. The attached list provides information on the nature of individual contracts in the $1982 / 83$ fiscal year.

CONTACT :

Name: J. Soos

Address: Forest Research Branch

Alberta Forest Service

215 McLeod Avenue

Postal Bag 6343

Spruce Grove, Alberta

TOE $2 \mathrm{CO}$

Phone: (403) 962-8700 
FINANCES :

$1982 / 83$ expenditure

Total funds spent to date

Projected expenditure for next five years
$\$ 360,000$

$\$ 873,000$

$\$ 1,800,000$

LIST OF STUDIES IN CURRENT FISCAL YEAR:

\section{Title}

1. Development of timedrelease biological repellents to control hare damage.

2. Factors affecting field performance of containerized and bareroot planting stock in Alberta.

3. Design for drainage system in forested peatland (Slave Lake Forest).

4. Mixedwood stand growth model development.

\section{Objectives}

To collect, isolate and identify volatiles (repellent odors) and to synthesize repe1lent compounds.

To assess field performance of bareroot and containerized seedlings planted by various planting techniques on three soil types.

To complete hydrometric network including drilling, pump testing, chemical analysis of water samples and design of drainage system.

To construct an individual-tree distance independent stand growth model for mixed aspen-spruce stands as an extension of a completed aspen model.
Investigator

T.P. Sullivan, Northwest Ecological Animal Research Ltd.

W.J. Ba11, CFS, NoFRC
J. Toth,
U. of Alberta

S.J. Titus,

$\mathrm{U}$. of Alberta 
To integrate the stand model with inventory data base so projections of stand dynamics can be made directly on inventory sample data.

To integrate stand model with management decision-making tools as the Timber Resource Allocation Mode1.

5. A study of the mating system and population structure of white spruce.

6. Quantitative genetics.
To determine whether the genetic structure of seed of individual trees of a white spruce stand significantly differs in two different seed years.

To quantify the magnitude and size of such differences, if they exist.

To determine outcrossing rates to identify marker alleles and to calculate heterozygosity for the stand.

To develop and design long-term breeding strategy for genetic improvement of major forest tree crops in Alberta.
B.P. Dancik, U. of Alberta
R.E. Stucker, U. of Minnesota 
To select methods and screening criteria in order to maximize genetic advance through selection and breeding.

7. Western gall rust.

8. Root growth potential.

9. Comparison of conventional yield tables with stand simulations and direct growth measurements.
To provide techniques and methods for screening of relative resistance against western gall rust of lodgepole pine families selected for genetic improvement.

To prepare a report on the review of literature and other available information pertaining to hormones regulating root regeneration of coniferous seedlings.

To elucidate discrepancies occurring between predictions developed by the conventional and Tree and Stand Simulator (TASS) system and to determine whether the two systems provide predictions consistent with direct growth data for permanent sample plots (PSPs).
D.M. Reid, U. of Calgary

W.R. Dempster, Forest management consultant 
Title

10. Description of forest associations in the southern subalpine zone and preparation of indicator plants of subalpine zone.
To make recommenda-

tions for improving

yield-prediction

techniques and for

priorizing the collec-

tion of growth data.

To prepare a technical Western

description of forest Ecological

plant associations in Services Ltd.

the southern region of

the subalpine zone,

and preparation of a

list of indicator

plants for the sub-

alpine zone. 


\subsection{A.3 Forest Research Branch (AFS) Project}

PROJECT :

Regeneration silviculture

RESPONSIBILITY CENTRE:

Forest Research Branch, Alberta Forest Service

CO-OPERATORS :

Canadian Forestry Service

Reforestation and Reclamation Branch, Alberta Forest Service University of Calgary

SOURCE OF FUNDING:

Government of Alberta

DURATION :

Long-term program with studies lasting five to ten years of more.

MAJOR OBJECTIVES:

1. To develop and test improved methods and techniques for efficient and effective nursery production of containerized and bareroot seedlings.

2. To determine the key factors and processes of plantation establishment and to develop the procedures and guidelines of stock handling, planting, and site preparation for optimizing the establishment, growth and development of plantations.

BENEFITS ON COMPLETION:

New techniques and improved methods for expanding nursery production will be developed to provide nursery managers with knowledge and guidelines for producing seedlings of the highest quality and simultaneously maintaining high productivity and 
efficiency of nursery operations. Benefits of the reforestation research are closely tied to the needs of expanding reforestation program. New technology will meet the increasing demands for high-quality and reliable methods of plantation establishment responsive to harvesting systems, site preparation treatments and site qualities.

HIGHLIGHTS OF ACCOMPLISHMENTS TO DATE:

Nursery research is in progress, developing improved procedures as related to dormancy, conditioning, storability and quality of seedlings.

Projects involving continuous and fall planting have been initiated together with studies of seedling attributes controlling postplanting performance.

Studies concerned with the improvement of survival and growth of plantations through mycorrhizal inoculations and optimization of microsite capacity on site-prepared areas are in development stage.

CONTACT :

Name: $\quad$ S. Navratil

Address: Forest Research Branch

Alberta Forest Service

215 McLeod Avenue

Postal Bag 6343

Spruce Grove, Alberta

TOE $2 \mathrm{CO}$

Phone: (403) 962-8700

FINANCES :
1982/83 expenditure
$\$ 95,000$
Total funds spent to date
$\$ 95,000$
Projected expenditure for next five years
$\$ 690,000$ 


\subsection{A.4 Forest Research Branch (AFS) Project}

PROJECT :

Ecosystem classification of forest lands in Alberta

RESPONSIBILITY CENTRE:

Forest Research Branch, Alberta Forest Service

CO-OPERATORS :

Canadian Forestry Service

Resource Evaluation and Planning Division (REAP), Alberta Energy and Natural Resources

Forest industries of Alberta

SOURCE OF FUNDING:

Government of Alberta

Government of Canada

DURATION :

Continuing long-term program (10 years)

MAJOR OBJECTIVES :

1. To characterize, describe and map homogeneous zones on a broad scale.

2. To characterize and describe the major forest and range ecosystems within the broad-scale zones.

3. To provide basic information in terms of structure, ecological characteristics and potential productivity of individual types of ecosystems.

4. To provide aids to field identification of these major forest and range ecosystems within the broad-scale zones. 
5. To develop management interpretations for the major types of ecosystems.

6. To promote the ecosystem concept in natural resource management.

7. To promote integrated resource management by providing a common land-base classification.

In order to make the information usable to operational foresters and technicians, field manuals are being developed to assist the individual practitioner in the field in recognizing types of ecosystems. It would be of great benefit if other inventory agencies in the province recognized the types of ecosystems while doing their mapping, which would provide the links required for integrated resource management.

BENEFITS ON COMPLETION:

A standardized ecosystem classification provides the common vocabulary necessary for communication among the various managers of natural resources. It establishes a common conceptual framework for such essential integrated land management planning activities as predicting, comparing and evaluating the consequences of different management strategies. The classification further serves as an information system for sitespecific land management and acts as a framework for organizing research projects and for transmitting research results to users in the field.

HIGHLIGHTS OF ACCOMPLISHMENTS TO DATE:

Since initiation of the classification project in 1976, AFS, CFS and REAP have established approximately 700 ecosystem plots. These agencies have prepared several progress reports, preliminary reports and journal articles. A booklet on zonation in southwestern Alberta was printed by AFS in 1980. Currently two studies are in progess. REAP is preparing an ecosystem classification report for the Sundre area (draft report target date April, 1983). CFS and AFS are preparing a field manual for describing and interpreting ecosystems in the field (draft 
report target date was July, 1983). A further major accomplishment during 1981 was the establishment of a data bank by REAP along with computer programs to manipulate data. The data bank and associated computer programs will encourage standardization of future ecological surveys in Alberta.

CONTACT :

Name: R.M. Annas

Address: Forest Research Branch

Alberta Forest Service

215 McLeod Avenue

Postal Bag 6343

Spruce Grove, Alberta

TOE $2 \mathrm{CO}$

Phone: (403) 962-8700

FINANCES :

1982/83 expenditure

$\$ 75,000$

Total funds spent to date

$\$ 75,000$

Projected expenditure for next five years

$\$ 480,000$ 


\subsection{A.5 Forest Research Branch (AFS) Project}

PROJECT :

Watershed management research.

RESPONSIBILITY CENTRE :

Forest Research Branch, Alberta Forest Service

CO-OPERATORS :

Forest Land Use Branch, AFS

Canadian Forestry Service

Forest industries

SOURCE OF FUNDING:

Government of Alberta

DURATION :

Continuing branch program, beginning February, 1983

MAJOR OBJECTIVES :

1. To determine impact of forest harvesting on the hydrology, hydrogeology and geomorphology on natural stream basins. In particular, soil erosion problems related to road cuts will be examined as will the watershed management implications of peatland drainage.

2. To develop mitigative measures for controlling possible negative impact of forestry operations on watersheds. Measures that utilize locally available forest materials (bioengineering technology) will be emphasized.

3. To develop techniques of forest management for the purpose of modifying streamflow characteristics, as required by user agencies. Data derived from the International Hydrological 
Decade watersheds will form the basis for this research.

BENEFITS ON COMPLETION:

Possible damage to natural streams should be predicted in advance. This would allow suitable mitigative measures and practices to be undertaken by the operator at the time of disturbance.

The results of research will be directed to solving practical problems encountered by user agencies in the management of water yield from forested lands. Questions of water quantity, water quality and sediment discharge in both time and space will be addressed.

HIGHLIGHTS OF ACCOMPLISHMENTS TO DATE:

This is a new program; however, several projects initiated elsewhere are operational. An empirical method for prediction of low flows on low order streams in undisturbed watersheds has been published and partly validated using one year of data. A semiquantitative method for prediction of soil erosion in connection with road construction and maintenance in the Grande Prairie area has been published.

CONTACT :

Name: D.T. Sneddon

Address: Forest Research Branch

Alberta Forest Service

215 McLeod Avenue

Postal Bag 6343

Spruce Grove, Alberta

TOE $2 \mathrm{CO}$

Phone: (403) 962-8700

FINANCES :

$1982 / 83$ expenditure

Total funds spent to date

$\$ 8,000$

Projected expenditures for next five years $\$ 450,000$ 


\subsection{A.6 Forest Research Branch (AFS) Project}

PROJECT:

Stand dynamics of second-growth stands following harvesting RESPONSIBILITY CENTRE:

Forest Research Branch, Alberta Forest Service CO-OPERATORS :

Forest industries

Other branches of Alberta Forest Service

SOURCE OF FUNDING:

Government of Alberta

DURATION :

Long-term program

MAJOR OBJECTIVES :

To monitor the establishment, mortality, ingress and subsequent growth of artificially and naturally established stands of lodgepole pine and white spruce originated after harvesting in Alberta. Long-term plots will be established and maintained in various biogeoclimatic subzones and plant associations representing different site qualities and reforestation treatments to obtain long-term yield information.

BENEFITS ON COMPLETION:

The permanent sample plots will provide sound information on the growth and development of stands originated after harvesting as a result of various reforestation techniques. 
HIGHLIGHTS OF ACCOMPLISHMENTS TO DATE:

Detailed project outline is currently in development stage. Fieldwork was anticipated during spring, 1983.

CONTACT :

$\begin{array}{ll}\text { Name: } & \text { J. Fochler } \\ \text { Address: } & \text { Forest Research Branch } \\ & \text { Alberta Forest Service } \\ & 215 \text { McLeod Avenue } \\ & \text { Postal Bag } 6343 \\ & \text { Spruce Grove, Alberta } \\ & \text { TOE } 2 \text { CO }\end{array}$

Phone: (403) 962-8700

\section{FINANCES :}

$1982 / 83$ expenditure

$\$ 2,000$

Total funds spent to date

$\$ 2,000$

Projected expenditure for next five years

$\$ 300,000$ 


\subsection{B.1 Reforestation and Reclamation Branch (AFS) Project}

PROJECT:

Applied reclamation research in the Green Area

RESPONSIBILITY CENTRE:

Reclamation Section, Reforestation and Reclamation Branch, Alberta Forest Service

CO-OPERATORS :

None

SOURCE OF FUNDING:

Government of Alberta

DURATION :

On-going

MAJOR OBJECTIVES :

1. To identify the cultural practices and management methods most useful for the successful reclamation of land-disturbance problem areas resulting from resource extractions.

2. To identify the cultivated and native plant species most desirable for reclamation, as well as the best methods for establishing desirable vegetation.

BENEFITS ON COMPLETION:

An economic and rapid, successful reclamation of land disturbances which restores productivity to that land. 
HIGHLIGHTS OF ACCOMPLISHMENTS TO DATE:

There is a series of experiments started after 1978, currently at various stages of completion. Results to date are given in a series of progress reports which are available to the public.

CONTACT :

$\begin{array}{ll}\text { Name: } & \text { S. Takyi } \\ & \text { P. King } \\ & \text { H. Tomm } \\ & \text { R. Islam }\end{array}$

Address: Reforestation and Reclamation Branch

Alberta Forest Service

9th Floor, Bramalea Building

9920 - 108 Street

Edmonton, Alberta

T5K $2 \mathrm{M} 4$

Phone: (403) 427-8474

FINANCES:

1982/83 expenditure

$\$ 6,000$

Total funds spent to date

$\$ 43,000$

Projected expenditure for next five years

$\$ 9,000$ 


\subsection{B.2 Reforestation and Reclamation Branch (AFS) Project}

PROJECT:

Provincial genetics and tree improvement program

RESPONSIBILITY CENTRE:

Genetics Section, Reforestation and Reclamation Branch, Alberta Forest Service

CO-OPERATORS :

Forest industries in Alberta

University of Alberta

Canadian Forestry Service

B.C. Forest Service

SOURCE OF FUNDING:

Government of Alberta

Alberta Heritage Savings Trust Fund

Forest industries in Alberta

University of Alberta

DURATION :

Long-term program with most projects lasting 20 years or more MAJOR OBJECTIVES:

1. To develop genetically-improved strains of seed of commercial forestry species in Alberta in order to enhance yield, hardiness, wood quality and pest resistance of future forests of Alberta.

2. To conduct basic and applied forest genetics and tree breeding research in order to develop new scientific knowledge and technology for genetic improvement of tree species and mass production of improved seed. 
3. To evaluate and demonstrate the merit of alternative tree species and provenances for commercial plantings.

4. To develop and maintain clone banks, seed and pollen banks and gene pool reserves for the perpetual preservation/ conservation of important forest gene resources and to provide germ plasm for scientific study and practical breeding.

5. To develop and prescribe system(s) for seed source movement controls and seed certification; and to develop a network of designated cone collection reserves in order to ensure that only high-quality seed is used for forest regeneration.

BENEFITS ON COMPLETION:

Realization of substantial increases in yield and wood quality of tree crops harvested from future forests in Alberta.

HIGHLIGHTS OF ACCOMPLISHMENTS TO DATE:

Work on the program was started in 1976 and major accomplishments up to 1982 are:

- Completed technical planning defining nature, scope, priorities and long-term direction of the program.

- Developed physical facilities for program work (laboratory and greenhouse complex at Pine Ridge, a network of experimental areas located throughout the province) and concluded cost and work sharing agreements with FMA industries with regard to co-operative work.

- Field selection of approximately 1,200 superior trees; acquisition of 2,360 research seedlots from 50 species; establishment of spruce and pine clone banks, research arboretum on white spruce seed orchard and 25 research plantations. 
- Work in progress at present on 32 research studies on genetics of white spruce and lodgepole pine; vegetative propagation, flowering enhancement and seed production technology; performance and variability of provenances and species collections.

CONTACT :

$\begin{array}{ll}\text { Name: } & \text { N. Dhir } \\ \text { Address: } & \text { Reforestation and Reclamation Branch } \\ & \text { Alberta Forest Service } \\ & 9 \text { th F1oor, Bramalea Building } \\ & 9920-108 \text { Street } \\ & \text { Edmonton, Alberta } \\ & \text { T5K } 2 \text { M4 }\end{array}$

Phone: (403) 427-8474

FINANCES :

$1982 / 83$ expenditure

\$ 470,000

Total funds spent to date

$\$ 1,295,000$

Projected expenditure for next five years

$\$ 2,625,000$ 


\subsection{B.3. Reforestation and Reclamation Branch (AFS) Project}

PROJECT:

Thinning and fertilizer factorial experiments in a young lodgepole pine forest (Edson)*

RESPONSIBILITY CENTRE:

Reforestation and Reclamation Branch, Alberta Forest Service CO-OPERATORS :

Department of Soil Science, University of Alberta

SOURCE OF FUNDING:

Government of Alberta

DURATION :

Long-term (with interim reports), up to over 30 years MAJOR OBJECTIVES :

The main objectives of the experiments are:

1. To compare tree growth under machine thinning in strips and the more conventional selective hand thinning with no thinning.

2. To study the effects of NPK fertilizers and rates on tree growth.

3. To study the interactions of fertilizers with thinning and thinning methods.

4. To study the fate of fertilizer nutrients applied to the forest (uptake by trees and nutrient levels in the soils). 
5. To study the influence of fertilizers (NPK) and nitrogen forms on cone production and seed quality.

6. To study the effects of two nitrogenous fertilizer forms and rates on tree growth.

7. To determine the influence of fertilizers on growth of forest floor vegetation.

BENEFITS ON COMPLETION:

Information from the experiments will aid in management decisions to improve commercial wood production.

HIGHLIGHTS OF ACCOMPLISHMENTS TO DATE:

Experiments were established only three years ago. Preliminary results of needle weight and needle length indicate a positive response to fertilizers and thinning. Rabbit damage is also closely related to the types of treatments and tree size.

CONTACT :

Name: S. Takyi

Address: Reforestation and Reclamation Branch

Alberta Forest Service

9th Floor, Bramalea Building

9920 - 108 Street

Edmonton, Alberta

T5K 2M4

Phone: (403) 427-8474

FINANCES:
1982/83 expenditure
$\$ 9,500$
Total funds spent to date
$\$ 13,500$
Projected expenditure for next five years
$\$ 9,500$

* Note: This is part of operational thinning in the Edson Forest. 


\subsection{B.4. Reforestation and Reclamation Branch (AFS) Project}

PROJECT:

Nursery investigations and research

RESPONSIBILITY CENTRE:

Pine Ridge Forest Nursery, Reforestation and Reclamation Branch, Alberta Forest Service

CO-OPERATORS :

Government of Alberta

SOURCE OF FUNDING:

Government of Alberta

DURATION :

On-going. Some projects are short-term.

MAJOR OBJECTIVES:

1. To provide information for developing improved seedling growing regimes.

2. To monitor the performance of seedlings.

3. To provide technical assistance for continuing improvements of production techniques and procedures in bareroot and container seedling growing and seed processing.

4. To develop effective controls of insects, diseases and weeds. 
BENEFITS ON COMPLETION:

Production of highest quality of seed and seedlings at acceptable cost.

HIGHLIGHTS OF ACCOMPLISHMENTS TO DATE:

Development of the fastest container seeding line known. Development of efficient production of very high quality seed and seedlings. Development of successful overwintering techniques for container stock. Development of effective topical application of fertilizer in bareroot seedbeds. Development of effective equipment which eliminates chemical pollution in herbicide applications. Selection of effective and economical cover crop species for fallow years.

CONTACT :

Name: R. Winn

Address: Pine Ridge Forest Nursery

Alberta Forest Service

Box 750

Smoky Lake, Alberta

TOA $3 \mathrm{CO}$

Phone: (403) 656-4130

FINANCES :

1982/83 expenditures

$\$ 11,000$

Total funds spent to date

$\$ 57,000$

Projected expenditure for next five years

$\$ 60,000$ 


\subsection{C.1 Forest Protection Branch (AFS) Project}

PROJECT:

Comparison of fire seasons and fire behavior in Alberta RESPONSIBILITY CENTRE:

Forest Protection Branch, Alberta Forest Service

CO-OPERATORS :

Atmospheric Services of Environment Canada

SOURCE OF FUNDING:

Government of Alberta

DURATION :

Short-term, one-to-two year studies

MAJOR OBJECTIVES :

To provide quantitative comparisons of fire season severity and to investigate fuel, terrain and meteorological factors associated with extreme fire behavior.

BENEFITS ON COMPLETION:

This project will provide better understanding when extreme fire conditions occur and preparedness level can be adjusted accordingly.

HIGHLIGHTS OF ACCOMPLISHMENTS TO DATE:

Investigations of synoptic weather changes and other conditions in relation to extreme fire behavior have been completed and reports concurrently prepared. 
CONTACT :

$\begin{array}{ll}\text { Name: } & \text { B. Janz } \\ \text { Address: } & \text { Forest Protection Branch } \\ & \text { Alberta Forest Service } \\ & \text { Box 7040, Station M } \\ & \text { Edmonton, Alberta } \\ & \text { T5K 5S9 } \\ & \text { (403) 427-7344 }\end{array}$

\section{FINANCES :}

$1982 / 83$ expenditure

$\$ 5,000$

Total funds spent to date

$\$ 2,200$

Projected expenditure for next five years

N/A 


\subsection{C.2 Forest Protection Branch (AFS) Project}

PROJECT:

Evaluation of airtankers and fire retardants on wildfires

RESPONSIBILITY CENTRE:

Forest Protection Branch, Alberta Forest Service

CO-OPERATORS :

Canadian Forestry Service

SOURCE OF FUNDING:

Government of Alberta

DURATION :

Completed

MAJOR OBJECTIVES :

To evaluate the various airtankers and long-term effectiveness

of retardants on wildfires in the initial attack mode.

BENEFITS ON COMPLETION:

The study will provide information on the effectiveness and accuracy of airtankers and retardants used in the initial attack mode.

HIGHLIGHTS OF ACCOMPLISHMENTS TO DATE:

Final report completed and published in NoFRC Forestry Report No. 28 (September 1983). Report titled "Evaluation of Air Tankers and Fire Retardants on Wildfires". 
CONTACT:

$\begin{array}{ll}\text { Name: } & \text { R. Lieskovsky } \\ \text { Address: } & \text { Forest Protection Branch } \\ & \text { Alberta Forest Service } \\ & 10625-120 \text { th Avenue } \\ & \text { Box } 7040, \text { Station M } \\ & \text { Edmonton, Alberta } \\ & \text { T5E 5S9 }\end{array}$

Phone: (403) 427-6807

\section{FINANCES :}

1982/83 expenditure

$\$ 50,000$

Total funds spent to date

$\$ 25,000$

Projected expenditure for next five years

$\$ 25,000$ 


\subsection{D.1 Forest Land Use Branch (AFS) Project}

PROJECT:

Tri-Creeks watershed study

RESPONSIBILITY CENTRE:

Forest Land Use Branch, Alberta Forest Service

CO-OPERATORS :

Edson Forest, AFS

Forest Research Branch, AFS

Groundwater Branch, Alberta Environment

Hydrology Branch, Alberta Environment

SOURCE OF FUNDING:

Government of Alberta

DURATION :

Current phase, 1977 to 1986

MAJOR OBJECTIVES :

1. To determine the effects of clearcutting on the survival, growth and reproduction of $\mathrm{fish}$ and aquatic invertebrate populations.

2. To determine the effects of streamside timber removal upon water temperature, streamflow and suspended sediment.

3. To determine the effects of clearcutting upon streamflow regime and the duration and magnitude of peak flows.

4. To determine the effects of road construction and clearcutting upon suspended sediment concentrations and stream channel siltation. 
5. To determine the effects of clearcutting upon the chemical quality of streams.

BENEFITS ON COMPLETION:

Information that can be used to establish sound land-use legislation which has a defensible, scientific basis will be derived from the study. In addition, methods for protecting and monitoring watersheds while forest and other resources are being harvested will be developed.

HIGHLIGHTS OF ACCOMPLISHMENTS TO DATE:

Pretreatment calibration and baseline fisheries data have been tabulated and published by the Fish and Wildlife Division and the Forest Land Use Branch for the period 1967-1977. Timber harvesting treatment will be completed in the current calendar year.

CONTACT :

$\begin{array}{ll}\text { Name: } & \text { G. Bergstrom } \\ \text { Address: } & \text { Forest Land Use Branch } \\ & \text { Alberta Forest Service } \\ & \text { 6th Floor, Bramalea Building } \\ & 9920-108 \text { Street } \\ & \text { Edmonton, Alberta } \\ & \text { T5K 2M4 }\end{array}$

Phone: (403) 427-3582

FINANCES :

1982/83 expenditure

$\$ 975,456$

Total funds spent to date

$\$ 100,000$

Projected expenditure for next five years

$\$ 511,000$ 


\subsection{E.1 Forest Products Research (AFS) Project}

PROJECT :

Forest industrial development research.

RESPONSIBILITY CENTRE:

Alberta Forest Sevice

Alberta Department of Economic Development

CO-OPERATORS :

Alberta Research Council

University of Alberta

Alberta Housing

Forest industry

SOURCE OF FUNDING:

Government of Alberta

DURATION :

Long-term

Individual studies of short-term nature, one to two years

MAJOR OBJECTIVES :

1. To ensure optimum allocation of Alberta's surplus forest resources through increasing, improving and updating management information required for forest industrial development decisions.

2. To assist forest industry in pursuing new markets for Alberta wood products.

3. To encourage mill modernization and upgrading of primary products through further secondary manufacturing. 
HIGHLIGHTS OF ACCOMPLISHMENTS TO DATE:

Nine studies were funded in 1982/83, the first year of operation for this particular program. Several other studies were completed from 1974 to 1982. A detailed list of studies in progress is attached.

CONTACT :

$\begin{array}{ll}\text { Name: } & \text { B.W. Karaim } \\ \text { Address: } & \text { Alberta Forest Service } \\ & 9 \text { th Floor, Petroleum Plaza, } \\ & \text { South Tower } \\ & 9915 \text { - } 108 \text { Street } \\ & \text { Edmonton, Alberta } \\ & \text { T5K 2C9 }\end{array}$

Phone: (403) 427-7418

FINANCES :

$\begin{array}{ll}1982 / 83 \text { expenditure } & \$ 750,000 \\ \text { Total funds spent to date } & \$ 450,000 \\ \text { Projected expenditure for next five years } & \$ 1,500,000\end{array}$

LIST OF STUDIES FUNDED IN CURRENT FISCAL YEAR:

Title

1. Shipment of $500 \mathrm{~m}^{3}$ of aspen logs to Japan for processing into

Japanese veneer and plywood.

2. To determine the optimum industrial strategy for utilizing Alberta's poplar resources.
Objectives

To determine the technical and economic feasibility of using Alberta aspen to produce Japanese-size veneer and plywood.

To provide the Alberta Jaakko Poyry government with strategic information on how best to develop Alberta poplar

resource.

Investigator

Shimane-ken

Plywood Association, Japan 
Title

3. An evaluation of

Alberta's secondary

forest products manu-

facturing industry.

4. An international poplar market study to assess both existing and potential uses for poplar.

5. To review the pulpchip pricing system in Alberta for the purpose of increasing pulp-chip production.

6. Subscription to Data Resources Inc. forest products marketing services.

7. Forest research needs for the management of aspen and poplar in Alberta.

8. To produce a manuscript for an information publication on aspen decay in Alberta.
Objective

To identify opportunities for expanding the secondary manufacturing industry by using local tree species.

To identify existing and potential markets for poplar products for purpose of encouraging industry to serve those markets from Alberta.

To identify those factors which government can alter to increase production of pulp chips in Alberta

To obtain and maintain up-to-date information on world supply and demand for forest products to be used in strategic planning.

To formulate a comprehensive poplar research and development strategy.

To provide a handbook for forest managers and operators harvesting aspen which describes operating guidelines relating to decay in commercial stands.

\section{Investigator}

Hallmark Engineering Ltd. and Woodbridge, Reed and Associates Ltd.

Carrol1-Hatch Ltd. Bowe 11

Consultants Ltd.

Data Resources Inc.

W.R. Dempster

$\&$ Associates

Ltd.

Canadian

Forestry

Service 
Title

9. To pulp samples of Alberta poplar using SCMP process developed by CIP.
Objective

To evaluate SCMP process as one more suited to handle poplar.
Investigator

CIP, Hawkes bury, Ontario 


\subsection{E.2 Forest Products Research (AFS) Project}

PROJECT:

Assessment of feasibility of building pilot demonstration plants in Alberta to advance specific poplar-based process technologies.

RESPONSIBILITY CENTRE:

Alberta Forest Service

CO-OPERATORS :

Alberta Department of Economic Development

Alberta Research Council

Private companies

SOURCE OF FUNDING:

Government of Alberta

DURATION :

Individual studies of short-term nature, one to two years Pilot plants could have a life span of two to 10 years.

MAJOR OBJECTIVES :

To advance the development of both new and existing technologies which will lead to increased utilization of poplar resource.

BENEFITS ON COMPLETION:

Commercialization of technologies leading to increased employment and expansion of the forest products industry.

Diversification within the forest products industry through integration. Increased and improved utilization of Alberta's forest resources. Development of high technology industry in Alberta with increase in secondary manufacturing sector. 
HIGHLIGHTS OF ACCOMPLISHMENTS TO DATE:

Two studies have been completed since 1981 under this particular program. One covered the feasibility of building a panelboard process development facility and the other a poplar-based chemical process development facility. Conclusions were that a panelboard facility would not encourage further expansion of the panelboard industry in Alberta.

However, the wood chemical study was positive to the extent that further negotiations are proceeding with the private sector in the hope that a pilot plant can be built.

CONTACT :

$\begin{array}{ll}\text { Name: } & \text { B.W. Karaim } \\ \text { Address: } & \text { Alberta Forest Service } \\ & 9 \text { th Floor, Petroleum Plaza } \\ & \text { South Tower } \\ & 9915-108 \text { Street } \\ & \text { Edmonton, Alberta } \\ & \text { T5K 2C9 } \\ & \text { (403) 427-7418 }\end{array}$

FINANCES :

$1982 / 83$ expenditure

Total funds spent to date

Projected expenditure for next five years
$\mathrm{Ni} 1$

$\$ 320,000$

$\$ 5,000,000$

LIST OF STUDIES FUNDED IN CURRENT FISCAL YEAR:

Title

1. Poplar chemical process development and demonstration facility.
Objectives

To prepare a conceptual design report including a review of the state of the art, the selection of the process equipment to be installed,
Investigator

W.L. Wardrop

Associates Ltd 
estimation of the

costs of construction

and operation, some

concepts of how the

facility may be

managed, a review of

markets for the prod-

ucts, and the develop-

ment of a research and

development program.

2. Analysis of poplarbased panelboard development program options for Alberta.
To provide an analysis of the present and future composition of the panelboard industry; to assess the value of a pilot plant to that industry as well as to Alberta, and to identify any other alternative industrial development incentives.
Carroll-Hatch Ltd. 
3. DIRECTORY OF ACTIVE RESEARCH PROJECTS

AND STUDIES BY VARIOUS AGENCIES

3.2 Alberta Research Council

Forest Products Research 


\subsubsection{Alberta Research Counc1l Project}

PROJECT:

Forest products research

RESPONSIBILITY CENTRE:

Alberta Research Council (ARC)

CO-OPERATORS :

Alberta Forest Service

Alberta Department of Economic Development

Alberta Housing

University of Alberta

Forest products industry

SOURCE OF FUNDING:

Government of Alberta

DURATION :

Long-term

Individual studies are of a shorter nature (one to five years).

MAJOR OBJECTIVES:

To address those forest products research problems that are unique to Alberta, particularly the ones dealing with the utilization of poplar. To assist the existing Alberta forest products industry in increasing productivity, improving fibre utilization and expanding markets.

BENEFITS ON COMPLETION:

Advance the full development of Alberta's forest resources by several years, thereby creating jobs, provincial royalties and tax revenues much sooner than expected. 
Contribute to diversification of Alberta's industrial base and encourage further upgrading of Alberta forest products.

HIGHLIGHTS OF ACCOMPLISHMENTS TO DATE:

ARC to have a testing laboratory and equipment in place and operational by March 31,1983 . This facility will allow it to conduct several CSA required tests on lumber and panelboard to prove those products are acceptable for particular end-use applications.

Thirteen projects were initiated in $1982 / 83$ and are listed below.

CONTACT :

$\begin{array}{ll}\text { Name: } & \text { B.W. Karaim } \\ \text { Address: } & \text { Alberta Forest Service } \\ & \text { 9th Floor, Petroleum Plaza } \\ & \text { South Tower } \\ & 9915-108 \text { Street } \\ & \text { Edmonton, Alberta } \\ & \text { T5K 2C9 } \\ \text { Phone: } & \text { (403) 427-7418 }\end{array}$

FINANCES :
$1982 / 83$ expenditure
$\$ 600,000$
Total funds spent to date
$\$ 525,000$
Projected expenditure for next five years
$\$ 3,500,000$

LIST OF STUDIES FUNDED IN CURRENT FISCAL YEAR:

$\underline{\text { Title }}$

1. Establishment of a forest products testing and development laboratory at ARC.

\section{Objectives}

To provide capability in Alberta for performing standard physical mechanical and chemical testing of wood and wood products grown and manufactured in Alberta.
Investigator

ARC 
Title

2. To conduct specific performance and code acceptance tests on Alberta softwood plywood.

3. To evaluate chemical properties of healthy and decayed aspen with focus placed on lignin and hemicellulose.

4. To demonstrate techniques of upgrading Alberta sawmills.

5. To conduct a technical evaluation of fingerjointing, edge-gluing and lamination of aspen lumber.

6. Development of a computer model for reconstituted wood products industry in Alberta.

7. To develop stress grading method for panelboard products and improve MSR system for lumber.

8. To assess new drying methods for poplar lumber.
Investigator

To generate enough data to support general acceptance of Alberta plywood.

To identify advantages and disadvantages of particular properties with respect to using aspen to produce wood chemicals.

To improve utilization through better recovery practices.

To develop valueadded uses for aspen and encourage further utilization of this species.

To assist present industry to improve overall process efficiency.

To assist industry in achieving and improving market acceptance for Alberta wood products.

To reduce both drying time and defects for aspen lumber.
Western Plywood Manufacturers Association

N. Cyr, ARC

Forintek

S. Chow, Canfor

T. Grabowski, U. of Alberta
ARC

Forintek 
$\underline{\text { Title }}$

9. To examine the effect of extreme temperatures on the mechanical behavior of aspen.

10. Development of new products from aspen bark.

11. To determine the anatomical, mechanical and physical properties of Alberta aspen.

\section{To determine the yield and quality of pulp chips produced from Alberta poplar.}

13. To carry out a technical assessment of jack pine and aspen shingles pressuretreated with wood preservatives and fire retardants.
To make adjustments and redesign equipment for processing aspen to improve overall efficiency and utilization.

To upgrade value of mill wastes and simultaneously improve resource utilization and economics of an integrated aspen manufacturing facility.

To relate these properties directly to specific end-uses for aspen to facilitate optimum management of this species.

To assist industry wishing to use poplar chips in pulp mills by establishing quantitative relationship between yield and predetermined levels of decay.

By means of retention and performance tests to determine acceptability of jack pine and aspen as suitable species on which to base shingle industry in Alberta.

\section{Investigator}

ARC

Northern Alberta Institute of Technology

M.M. Micko, $\mathrm{U}$. of Alberta

Woodbridge, Reed $\&$ Associates and Econotech Ltd.

Cold Lake Indian Band 
3. DIRECTORY OF ACTIVE RESEARCH PROJECTS AND STUDIES BY VARIOUS AGENCIES

\subsection{Canadian Forestry Service Northern Forest Research Centre}




\subsubsection{Canadian Forestry Service Project}

PROJECT:

Silviculture investigations

RESPONSIBILITY CENTRE:

Northern Forest Research Centre

CO-OPERATORS :

Alberta Forest Service

Saskatchewan Forest Service

Manitoba Forest Service

Forest industries

DURATION :

Long-term

MAJOR OBJECTIVES :

1. To undertake basic and operationally-oriented research in seedling production, conditioning, storage and field performance; seed and seedling physiology; and forest ecology and site productivity in support of prompt forest regeneration following harvesting.

2. To provide forest managers with information, guidelines and prescriptions for improving the level of regional forest regeneration management in tree nurseries and in field planting operations.

BENEFITS ON COMPLETION:

The major benefits will be improved tree seedling production and reforestation of harvested lands and enhanced levels of wood production at reduced costs per unit area treated. 
Between 1958 and 1979, this project concentrated on assessing and developing site preparation techniques (including scarification and prescribed burning), developing and assessing container planting systems (including work on container type and size), and developing guidelines for rearing containerized seedlings (covering a range of production criteria from seed through to nutrition and hardening-off of stock). Work has continued to the present to ascertain preplanting conditioning and overwintering techniques to reduce losses and improve field performance of stock produced in the region. Reporting is now underway on the effects of frost and other agents on the establishment of spruce and pine container stock and on field structures to minimize field storage damage.

Performance of both bareroot and container stock planted under a range of field conditions continues, through assessments of past CFS research plots and through a contract with the Alberta Forest Service Research Branch. A silviculture data bank is being developed to provide background data in support of silvicultural prescriptions and decision aids. The bank will have a national component using data collected and reported by NoFRC as part of the Canadian Forest Resource Data program. A report outlining silviculture statistics for Canada, 1975-1980, has been published.

There has been a continuing and effective liaison service in nursery management, cultural operations, and disease control throughout this project. The liaison function has become especially significant since 1976 with the rapid increase in high-technology greenhouse production of containerized seedlings at both government and industrial nurseries throughout the region. At the same time there has been expansion in soil management and nutrition as well as insect and disease control. Two recent workshops in the Edmonton area have resulted in Information Reports NOR-X-235, "High-quality collection and production of conifer seed", and NOR-X-241, "Proceedings of the 1981 Intermountain Nurserymen's Association meeting". Demand continues to be strong for Information Report NOR-X-214, "Guidelines for rearing containerized conifer seedlings in the Prairie provinces". 
Recently, studies have been initiated in tree seed and seedling physiology, especially the latter as it relates to cold hardening and dormancy processes. Forest ecology and site productivity research is also underway, with emphasis on synthesizing forest association, vegetation and environmental descriptions within a biogeoclimatic framework and helping to develop a forest management field guide based on forest associations in conjunction with the Alberta Forest Service and provincial industries. During 1982 mechanization of the silviculture component was added to the project with initial emphasis on a regional equipment inventory and plans to undertake equipment evaluations.

CONTACT :

Name: L.G. Brace

Address: Northern Forest Research Centre 5320 - 122 Street

Edmonton, Alberta

T6H $3 \mathrm{~S} 5$

Phone: (403) 435-7210

\section{FINANCES :}
1982/83 expenditure
$\$ 645,000$
Projected expenditure for next five years
Increase

LIST OF STUDIES IN CURRENT FISCAL YEAR:

Title

1. Nursery operations.
2. Nursery soil fertility and seedling growth.
Objectives

To improve general nursery practices, including seedling production and cultural operations.
To determine the I.K. Edwards
Investigator

Vacant nutrient requirement for growth and hardening off of bareroot 


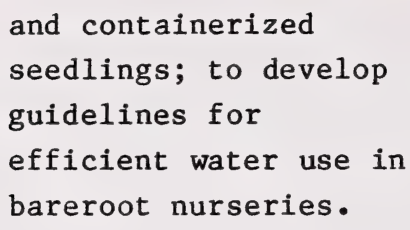

3. Conditioning, winter storage and initial field performance of containerized conifer seedlings.

4. Development of silviculture data base and management tools for forest resource planners.

5. Field performance of planted stock.

6. Forest tree seed and seedling physiology. physiological aspects
To develop overwintering guidelines for containerized seedlings; to study effects of microclimate and ice nucleating agents

(INA) on cold tolerance of seedlings.

To develop and disL.G. Brace seminate silvicultural prescriptions and guidelines; to undertake studies in the field of mechanized regeneration equipment.

To carry out research W.J. Ball to assess and improve the field performance of planting stock.

To investigate the I.J. Dymock
H. Zalasky of cone and seed production, conditioning and physiological testing of planting stock; as a registered 
seed analyst within the OECD scheme certifies forest reproductive material moving in international trade.

7. Forest ecology and site productivity.

To quantify site/

I.G.W. Corns

forest productivity

relationships; to

determine the relative

contribution of site

nutrient regimes,

climate and soil

moisture to the

productivity of boreal

forest ecosystems; to

evaluate the effects

of modifying soil

physical and biologi-

cal properties on

seedling growth.

8. Silvicultural research

To assess, maintain

W.J. Ball

and technology

and conduct silvi-

transfer, Manitoba and cultural research, Saskatchewan.

field trials and demonstrations in

Manitoba and

Saskatchewan; to provide technology transfer in the field of silviculture and identify forest management problems requiring research. 


\subsubsection{Canadian Forestry Service Project}

PROJECT:

Yields of managed stands

RESPONSIBILITY CENTRE:

Northern Forest Research Centre

CO-OPERATORS :

Alberta Forest Service

St. Regis (Alberta) Ltd.

DURATION :

Long-term

MAJOR OBJECTIVES:

1. To develop and assess silvicultural operations (i.e. initial spacing) and treatments (thinning, fertilizing) for increasing the yield of managed stands.

2. To provide forest management agencies with improved techniques and models for growth and yield prediction for commercially important cover types.

BENEFITS ON COMPLETION:

The major benefit will be enhanced levels of wood production at reduced costs per unit area treated. Growth prediction will enable the forest manager to monitor more effectively the annual allowable cut. 
Numerous long-term studies initiated in the past to provide prescriptions for spacing, thinning and fertilization of lodgepole pine, jack pine, white spruce and trembling aspen in the region are being monitored; the results will be published as they become available.

During 1982-83, reports were published on spacing and thinning effects in seven- 25- and 77-year-old lodgepole pine; a journal article was published on the effects of strip thinning on the growth of lodgepole pine 15 years after treatment. Test runs and calibration of components (potential diameter growth function, modifier function, crown ratio function, maximum basal area and mortality function) of a stand-growth simulation model (STEMS) progressed to the stage for aspen and jack pine to initiate operational implementation. At the request of the Alberta Forest Service Research Branch an intensive short-term study was carried out to determine the effect of line-clearing (seismic, pipe, etc) on tree and stand growth and yield in the commercial forest zones of western Alberta. Data analysis has been completed and a report prepared.

A fertilization study in 30- and 70-year-old lodgepole pine at Hinton, established 10 years ago with five levels of $N, P$ and $S$, has been remeasured and the analysis of treatment response in terms of stem diameter, height, basal area and stem volume per hectare is proceeding. Soil and foliage samples were also collected to determine $N, P$ and $S$ levels and to relate these elements to tree growth Publications are currently being prepared.

CONTACT :

$\begin{array}{ll}\text { Name: } & \text { I.E. Bella } \\ \text { Address: } & \text { Northern Forest Reseach Centre } \\ & 5320-122 \text { Street } \\ & \text { Edmonton, Alberta } \\ & \text { T6H 3S5 } \\ \text { Phone: } & \text { (403) 435-7210 }\end{array}$


FINANCES :

1982/83 expenditure

$\$ 260,00$

Projected expenditure for next five years

Increase

LIST OF STUDIES IN CURRENT FISCAL YEAR:

Title

1. Growth and yield of five commercially important native species in Alberta, Saskatchewan and Manitoba.
Objectives

To construct yield tables for use in natural, unmanaged lodgepole pine, jack pine and aspen stands; to determine the effect of different types and intensities of thinning on growth and yield of lodgepole pine, jack pine and aspen; to assess the effect of spacing on the growth and develop ment of white spruce, red, jack and lodgepole pines.

2. Stand modelling of the growth and development of important forest types in the Prairie provinces.

3. Fertilization of established lodgepole pine stands.
To forecast growth and yield of forest stands under a range of site and density conditions using a stand growth model developed for this purpose.

To assess the effects of fertilizing 70year-old and 30-yearold lodgepole pine stands on growth and yield.
Investigator

I.E. Bella
I.E. Bella,

H. Grewal

R.C. Yang 
$\underline{\text { Title }}$

4. Transformation and movement of applied fertilizer elements $(\mathrm{N}, \mathrm{P}, \mathrm{S})$ in selected lodgepole pine stands.

5. Fertilization and thinning of semimature lodgepole pine stands.
To determine the

J. Baker influence of soil on the transformation, distribution and accumulation of $\mathrm{N}, \mathrm{P}, \mathrm{S}$ fractions following fertilization in lodgepole pine stands.

To assess the effects R.C. Yang,
of thinning and
fertilizing semimature
lodgepole pine on stand
growth; to assess the
contribution of
individual fertilizer
elements to the growth
response; to develop a
diagnostic technique
for prescribing
nutrient requirements
for lodgepole pine
stands in the foot-
hills of Alberta.




\subsubsection{Canadian Forestry Service Project}

PROJECT :

Tree improvement

RESPONSIBILITY CENTRE:

Northern Forest Research Centre

CO-OPERATORS :

Alberta Forest Service

Saskatchewan Forest Service

Manitoba Forest Service

DURATION :

Long-term

MAJOR OBJECTIVES:

1. To improve the quality of reforestation stock for use by forest land managers by breeding or identifying and introducing genetically superior populations of commercial forest species.

2. To produce genetically improved grafts, seedlings or rooted cuttings of seedlings of jack pine in sufficient quantity for establishment by co-operators of plantations for mass production of genetically improved planting stock.

BENEFITS ON COMPLETION:

Development of jack pine seed orchards or the introduction of genetically improved stock of other commercial tree species will lead to reduced seed procurement costs and increased wood yields per unit area planted. 
HIGHLIGHTS OF ACCOMPLISHMENTS TO DATE:

Family test plantations using field-selected jack pine progenies have been established in southeastern Manitoba (eastern district), in the uplands along the Manitoba-Saskatchewan boundary (central district) and in the southern portion of the forest zone in Saskatchewan (western district). Jack pine sources obtained in eastern Alberta are included in the latter test area. Ten year remeasurements have been carried out in the eastern family test plantations. Selection of the 40 best families, based on height, diameter and volume growth, as well as form, provides the materials that will be used in the establishment of seed orchards in southeastern Manitoba. The 10-year remeasurement of family test plantations in the western district will be carried out in 1983 and for the central district in 1985. Further improvements in genetic quality will be realized in the next and recurrent selections with appropriate deletions and additions being made to the district seed orchards.

Provenance tests involving Norway spruce, white spruce, black spruce, jack pine, red pine and Scots pine have been established and are remeasured and reported upon periodically.

CONTACT :
Name: J.I. Klein
Address: Northern Forest Research Centre 5320 - 122 Street
Edmonton, Alberta
T6H 3S5
Phone: (403) 435-7210

FINANCES :

1982/83 expenditure

$\$ 105,000$

Projected expenditure for next five years

Increase 
LIST OF STUDIES IN CURRENT FISCAL YEAR:

$\underline{\text { Title }}$

1. Breeding jack pine for the northern region.
Objectives

To identify jack pine genotypes that are genetically superior in terms of economic yield for areas of significant jack pine planting activity; to produce scions or control-pollinated seed of superior genotypes for propagation of seed orchards; to identify genetically superior source scions for seed collection.

2. Provenance tests for coniferous species.
Investigator

J.I. Klein 


\subsubsection{Canadian Forestry Service Project}

PROJECT:

Detection and appraisal of forest insects and disease (FIDS)

RESPONSIBILITY CENTRE:

Northern Forest Research Centre

CO-OPERATORS :

Alberta Forest Service

Saskatchewan Forest Service

Manitoba Forest Service

Parks Canada

Provincial departments of Agriculture

DURATION :

Long-term

MAJOR OBJECTIVES:

1. To gain an improved knowledge of major forest insects and diseases in the region for the purpose of understanding and minimizing damage attributable to these organisms.

2. To contribute to a national overview of important pest conditions.

3. To develop or modify survey and appraisal methods for assessment of losses caused by major forest pests.

4. To provide advisory services to various client agencies concerning forest insect and disease problems. 
BENEFITS ON COMPLETION:

The major benefits will be an enhanced understanding of the biology and impact of insects and diseases on the forest resource. This understanding will serve as a basis for evaluating forest volume losses and impact on stand management. An increased knowledge of biology will contribute to the development of control procedures.

HIGHLIGHTS OF ACCOMPLISHMENTS TO DATE:

Annual surveys of important pest and conspicuous forest damage have been conducted since 1941. Major insect and disease outbreaks have been monitored and their impacts on the forest resource have been assessed. Major insect pests in the region include mountain pine beetle, spruce budworm, jack pine budworm and forest tent caterpillar. Pine stem rusts, root rots and poplar diseases are the major forest diseases. Dutch elm disease is a major urban disease problem in Manitoba.

With the intensification of forest management there has been a gradual change in emphasis from wild, unmanaged stands to reforested areas and nurseries. Aerial surveys are still conducted on major outbreaks but detailed examinations will likely be more common in managed stands.

A pest extension service for a broad clientele has been continued for many years. More than 2000 enquiries are processed annually. Priority is given to forested land but there is a strong demand from urban and agricultural clients.

CONTACT:

Name: B. Moody

Address: Northern Forest Research Centre

5320 - 122 Street

Edmonton, Alberta

T6H $3 \mathrm{~S} 5$

Phone: (403) 435-7210 
FINANCES:

$\begin{array}{ll}1982 / 83 \text { expenditure } & \$ 440,000 \\ \text { Projected expenditure for next five years } & \text { Increase }\end{array}$

LIST OF STUDIES IN CURRENT FISCAL YEAR:

Title

1. Forest insect and disease survey.

2. Sawfly systemics.

\section{Objectives}

To gain an improved knowledge of forest insects and disease in the region, thereby minimizing damage to trees and shrubs; to provide management agencies with diagnostic impact and appraisal services relating to the effects of pests, climatic influences and pollutants on trees and shrubs; to contribute to a national overview of important pest conditions.

To undertake biosystematic studies on the sawflies of Canada; to separate various sawf $1 y$ species by means of keys, descriptions and illustrations.

\section{Investigator}

B. Moody

H.R. Wong 
Title

3. Control and damage impact of insect injuries to trees and shrubs.
Objectives

To maintain up-to-date information and provide technical and advisory services on insect problems of trees and shrubs common to the region, laws related to pesticides and their usage, insect control methods, and effects of pesticides on the environment; to develop information on specific insect problems of the region with respect to distribution, abundance, hazard, damage impact and control.

4. Forest insect diagnostic and biosystematic services.

5. Damage appraisal of major forest pests.

\section{Investigator}

H.F. Cerezke 


\subsubsection{Canadian Forestry Service Project}

PROJECT:

Forest insect and vegetation management systems

RESPONSIBILITY CENTRE:

Northern Forest Research Centre

CO-OPERATORS :

Alberta Forest Service

St. Regis (Alberta) Ltd.

Manitoba Forest Service

DURATION :

Long-term

MAJOR OBJECTIVES:

1. To evaluate the effectiveness of herbicides and pesticides in regeneration forestry and to develop methods for incorporating them as tools in forest management.

2. To determine the factors affecting the survival and growth of lodgepole and jack pine from establishment to age 35 .

3. To evaluate the importance of seed and cone insects in the production of coniferous seeds.

4. To evaluate the feasibility of using pheromones for assessing the abundance and control of forest insects.

BENEFITS ON COMPLETION:

Efficacy testing of chemicals is related to pesticides, herbicides and pheromones. These tests and subsequent environmental impact studies will ultimately assist in the registration of new and improved chemicals for forest management purposes. 
The impact of seed and cone insects, particularly on white spruce, is of major importance to the Prairie provinces. An inventory of these insects and biological studies is necessary in order to develop control methods.

Information on the survival and growth of lodgepole pine to age 35 (where yield table information is available) is not known. This has major implications regarding juvenile spacing. Several hundreds of small plots have been established on reforested areas of the St. Regis (Alberta) lease near Hinton, Alberta, to determine losses following stand establishment and to assess mortality factors. A similar study being carried out in jack pine plantations in Manitoba will provide spacing guidelines for that species.

\section{HIGHLIGHTS OF ACCOMPLISHMENTS TO DATE:}

A comprehensive field test of liquid and granular herbicides has been conducted. Further evaluations will be done; environmental impact studies will be conducted in the near future.

Field testing of pheromones for box elder twig borer and pitch nodule makers has been completed. The formulations were effective in attracting these species of insect.

An inventory of cone and seed insects of white spruce is being conducted. Cone samples have been received from all forest districts in Alberta and examinations are underway to determine insect species and damage done to seeds. Preliminary testing of Bidrin and Metasystox $R$ injected into white spruce trees gave good control of seed insects. Soil drench treatments of three chemicals were not effective, probably due to drought conditions, and these treatments will be repeated.

Approximately $20003 \times 3 \mathrm{~m}$ plots were established in cut-over, scarified areas of various ages and sites. Natural lodgepole pine on these plots have been tagged for remeasurement and the first-year remeasurement completed. Where possible, mortality factors are determined. This study will provide information on mortality and growth of young lodgepole pine from age 10 to 35 . This information is necessary to provide early stocking guide- 
lines and will assist in preparing stand treatment prescriptions. A similar study is carried out in jack pine plantations in Manitoba.

CONTACT:

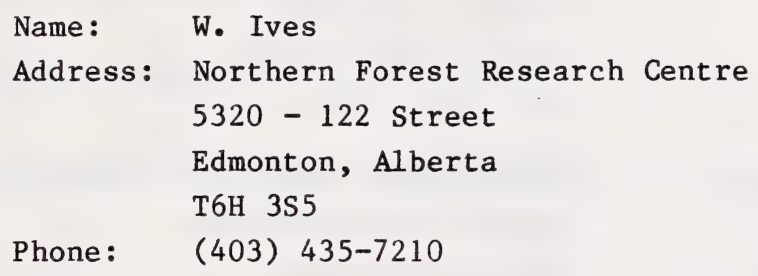

FINANCES :

$\begin{array}{ll}1982 / 83 \text { expenditure } & \$ 200,000 \\ \text { Projected expenditure for next five years } & \text { Increase }\end{array}$

LIST OF STUDIES IN CURRENT FISCAL YEAR:

\section{Title}

1. Chemical controls of pests and vegetation in managed forests.
Objectives

To develop control methods and assess needs on the use of herbicides and pesticides and to evaluate pheromones as a tool

in forest management; to conduct efficacy trials for various dosages, formulations and timing, and to determine present mortality of host species; to provide data to aid registration recommendations for selected chemical products.

\section{Investigator}

J. Drouin 
$\underline{\text { Title }}$

2. Evaluation of mortality in stands of young trees in plantations and scarified areas.

3. Insects and diseases affecting seed production in the Prairie region.

\section{Objectives}

To determine the effect of site on survival of lodgepole and jack pine; to prepare a set of survival curves for each site class.

To determine the species and abundance of cone and seed insects and their importance in the production of coniferous seed; to study the natural enemy complexes of each pest species and the extent of mortality exerted by these natural enemies.

\section{Investigator}

W. Ives,

K. Froning

J. Muldrew 


\subsubsection{Canadian Forestry Service Project}

PROJECT :

Tree disease research

RESPONSIBILITY CENTRE:

Northern Forest Research Centre

CO-OPERATORS :
Alberta Forest Service
University of Alberta

DURATION :

Long-term

MAJOR OBJECTIVES:

1. To conduct research on the biology, pathology and epidemiology of selected forest tree diseases, especially forest tree rusts and other diseases of intensively managed young conifer forests.

2. To determine the effects of ice nucleating agents on cold to tolerance of seedlings and to develop effective overwintering guidelines to enhance field performance.

BENEFITS ON COMPLETION:

Major benefits include forest management control measures for important diseases in young plantations and the development of overwintering guidelines for storage of nursery stock.

HIGHLIGHTS OF ACCOMPLISHMENTS TO DATE:

Although important forest pathology research was done at NoFRC in the 1950s and 1960s, it was relegated to a relatively minor component of the research program in the 170 s and became part of 
the Forest Insect and Disease Survey. Recently, forest pathology research has been identified as a separate project because of the increasing importance of forest disease losses in relation to intensive forest management, particularly reforestation.

Present work is concentrated on stem rusts and root rots which are common in coniferous plantations and natural regeneration following seed-bed treatment. Co-operative work with the University of Alberta is underway and two graduate students are engaged in work with the project leader on western gall rust and Armillaria root rot. Funding from the Alberta Forest Development Research Trust Fund, and a strategic grant from National Science and Engineering Research Council (NSERC) is received. An investigation of blue-stain fungus associated with the mountain pine beetle is being conducted under the NSERC grant.

An illustrated publication on poplar diseases was prepared under a jointly funded contract (AFS, Alberta Energy Ltd.) and was supervised by the project leader. This publication summarizes knowledge on poplar diseases and is a "state-of-the-art" publication dealing with the implications of diseases on management of the species.

The effects of ice nucleating agents on the cold tolerance of coniferous tree seedlings are being studied. Overwintering guidelines to enhance field performance will be developed. Also, a manual describing frost damage to vegetation will be prepared.

CONTACT :

$\begin{array}{ll}\text { Name: } & \text { Y. Hiratsuka } \\ \text { Address : } & \text { Northern Forest Research Centre } \\ & 5320-122 \text { Street } \\ & \text { Edmonton, Alberta } \\ & \text { T6H 3S5 } \\ \text { Phone: } & \text { (403) } 435-7210\end{array}$


FINANCES :

$\begin{array}{ll}1982 / 83 \text { expenditure } & \$ 120,000 \\ \text { Projected expenditure for next five years } & \text { Increase }\end{array}$

LIST OF STUDIES IN CURRENT FISCAL YEAR:

\section{Title}

1. Forest tree rusts of western North America.

2. Forest disease research and technical transfer services.

\section{Objectives}

To study aspects of the cytology, taxonomy, life history and hostparasite relationship of conifer needle rusts, pine stem rusts and poplarconifer rusts of the region.

To conduct short-term investigation of tree diseases as need arises; to prepare checklists of forest fungi of important areas and diagnostic keys for identification.

To determine the effects of ice nucleating agents and microclimate on cold tolerance of seedlings and juvenile trees and to use knowledge gained to develop more effective overwintering guidelines to enhance field performance; to investigate red belt symptoms, winter browning, bark discoloration and subsequent severe defoliation, and changes in refoliation patterns.

\section{Investigator}

Y. Hiratsuka

Y. Hiratsuka

H. Zalasky 


\subsubsection{Canadian Forestry Service Project}

PROJECT:

Fire management systems and guidelines

RESPONSIBILITY CENTRE:

Northern Forest Research Centre

CO-OPERATORS :

Alberta Forest Service

Saskatchewan Forest Service

Manitoba Forest Service

Department of Indian Affairs and Northern Development (NWT)

Parks Canada

DURATION :

Long-term

MAJOR OBJECTIVES:

1. To provide guidelines and standards for operational use that will, reduce at an acceptable cost the damage and losses from fires while considering the related economic, ecological and social factors.

2. To develop fire behavior guides for regional fuel types and integrate them with the Canadian Fire Weather Index (CFWI).

3. To elucidate the natural role of fire and describe fire effects on forest ecosystems.

4. To provide precise information on airtanker performance, fire retardant performance and effectiveness, retardant airdrop patterns, improved fireline productivity, and fire detection systems and methodology. 
5. To develop, test and promote the application of models simulating various suppression activities at the field operational level and directed toward improved utilization and effectiveness of funds, manpower and equipment.

\section{BENEFITS ON COMPLETION:}

Benefits include reduced fire suppression costs and resource losses; more effective and efficient fire detection and presuppression systems; and a better understanding of fire effects on forest ecosystems.

HIGHLIGHTS OF ACCOMPLISHMENTS TO DATE:

Airtanker and retardant effectiveness was investigated on 18 wildfires in co-operation with the Alberta Forest Service. Retardant and water drop trials (Bell 205) and assessment of tank and gating modifications (DC-6B) were completed. Technical assistance was provided to industries engaged in the development of a prototype vinyl helibucket.

A national fire behavior data base by fuel type (experimental fires and selected wildfires from Canada and the U.S.A.) was assembled during two working meetings of the CFS danger-rating group. Interim descriptive danger index classes associated with the proposed Fast-Drying Spread Index (FDSI), a fire danger climatology for the new Sun-exposed Fine Fuel Moisture Code (SFFMC), and spring drought code starting values associated with the Canadian Forest Fire Danger Rating System were provided to fire management agencies in the region. A 10-day experimental burning project was conducted in the black spruce- 1ichen woodland fuel complex at Porter Lake, N.W.T., by fire research staff from PRFC, GLFRC, PNFI and NoFRC. Ten experimental (seven line and three point source ignitions) and one wildfire were documented under low to extreme fire danger conditions.

Procedures for organizing the historical regional fire data bank have been initiated. Regional fire statistics are being collected and a fire history atlas for Alberta is nearing completion. 
Work continued toward developing improved methods of detecting lightning fires using thermovision, a scan extender and the LLP system. An inexpensive, portable fire-finder developed for Saskatchewan is now MOT approved. Using a Navaho aircraft, several thermovision lenses were tested for sensitivity and coverage while flying at different speeds and elevations. Five lightning fires were documented in Saskatchewan to gather data in support of a lightning fire prediction model.

Fieldwork, necessary for the construction of seen area maps, was completed for 11 towers in Riding Mountain National Park. As part of a continuing study on the use of fire in vegetation management, park personnel were assisted in a prescribed burn at Elk Island National Park in the spring of 1982.

Four forest management notes were published including guidelines for use of the AGA Thermovision in mop-up operations, guidelines for water-thickening compounds used in fire control, initialattack planning with a programmable hand-held calculator, and the calculating of spring drought code starting values in the region. A total of 20 reports are currently being prepared, addressing such subjects as: fire detection, fire behavior, fire history, fire danger rating, fire suppression, and fire effects following prescribed fire.

The fire group participates extensively in technology transfer and in meetings, workshops, committees, training sessions and lectures with forestry agencies and schools.

CONTACT :

Name: D.E. Dube

Address: Northern Forest Research Centre 5320 - 122 Street Edmonton, Alberta T6H 3S5

Phone: (403) 435-7210

FINANCES :

1982/83 expenditure $\$ 345,000$

Projected expenditure for next five years

Stable 
LIST OF STUDIES IN CURRENT FISCAL YEAR:

Title

1. Fire behavior in boreal forest fuels.
Objectives

To develop fire spread and intensity tables

for major fuel com-

plexes; to assess fire

effects in terms of

fuel reduction and

plant succession over

a range of burning

conditions; to estab-

lish guidelines for

rational uses of fire

in manipulation of

various fuel combinations.

To develop plans for

C.J. Ogilvie wildfire surveillance

and communication

systems for the North-

west Territories and

other clients; to

identify the most

advantageous detection

system for given

conditions; to define

and identify factors

influencing the design

of wildfire detection

and communication

systems; to develop

effective wildfire

mapping and surveil-

lance techniques.

To develop and imple-

D.E. Dube

ment fire management

G. Delisle
Investigator

Z. Chrosciewicz of fire in forest and

intermingled vegetation

in the Prairie provin- programs in designated

national parks; to 
$\underline{\text { Title }}$

ces, Rocky Mountains, and Far North.

4. Decision-aid models for use in fire management.
5. Fire danger and behavior rating in forest and rangeland environments.
Objectives

define the needs and priorities of client agencies in the area of fire impact assessments.

To identify the key factors relating to the occurrence, behavior and effect of wildfires on the cost effectiveness of fire-control decisions; to build, test and operate relevant decision-aid models designed to assist fire-management agencies in optimizing the allocation and use of available resources during demanding or multiple fire occurrence situations.
D.E. Dubé

R.G. Newstead

G. Delisle

M.E. Alexander
To develop, evaluate,

M.E. Alexander interpret and apply the Canadian Forest Fire Danger Rating System; to improve the assessment and prediction of wildfire behavior in terms and by methods which are useful to fire management agencies. 


\subsubsection{Canadian Forestry Service Project}

PROJECT:

Reduction of damage from pollutants in the atmosphere

RESPONSIBILITY CENTRE:

Northern Forest Research Centre

CO-OPERATORS :

Alberta Environment

Canterra Energy Co. Ltd.

Gulf Canada Ltd.

DURATION :

Long-term

MAJOR OBJECTIVES:

1. To provide federal and provincial regulatory agencies with scientific data for setting improved air-quality standards on a national level for single and mixed pollutants.

2. To provide federal, provincial and industrial resource managers with techniques and methodology for detecting and assessing air-pollution impact on forest vegetation and soils and for restoring affected sites.

BENEFITS ON COMPLETION:

Benefits include improved air-quality standards and appropriate regulations; improved techniques for assessing air pollution impacts and remedial measures.

HIGHLIGHTS OF ACCOMPLISHMENTS TO DATE:

Descriptive studies on the pattern and impact of pollutant deposition have been carried out in the Athabasca oil sands area 
and near two sour gas plants in west-central Alberta. Both laboratory and field studies including physiological, biochemical and ecological responses of vascular plants and lichens to air-borne pollutants have resulted in biomonitoring techniques, some of which have shown promise for practical application while others are being defined more clearly. Studies on the natural environmental and biotic factors influencing pollutant uptake by or impact on boreal forest plant species are underway. Preliminary results indicate that further studies, particularly on mixtures of pollutants and elemental sulphur, are required before the capability to predict pollutant impact on forest components can be developed. Detailed studies on the deposition of pollutants and resultant changes in soil chemistry are underway.

A handbook, "Diagnosis of air pollutant and natural stress symptoms on forest vegetation in Western Canada", has been published.

CONTACT :

$\begin{array}{ll}\text { Name: } & \text { P.A. Addison } \\ \text { Address: } & \text { Northern Forest Research Centre } \\ & 5320-122 \text { Street } \\ & \text { Edmonton, Alberta } \\ & \text { T6H } 3 \mathrm{~S} 5\end{array}$

Phone: (403) 435-7210

FINANCES :
1982/83 expenditure
$\$ 180,000$
Projected expenditure for next five years
Stable

LIST OF STUDIES IN CURRENT FISCAL YEAR:

\section{Title}

1. Assessment of air pollution impact on forest systems.

\section{Objectives}

To describe and assess changes in the forest ecosystem as a result of two sour gas plants in west-central

\section{Investigator}

P.A. Addison

D.G. Maynard 
Alberta; to determine the mechanism of elemental sulphur dust impact to the forested soil-plant system.

2. Impact of air pollutant

To determine the D.G. Maynard mixtures on forest sensitivity of boreal plant species to air pollutants and the influence of environmental factors, including soils on plant sensitivity. 


\subsubsection{Canadian Forestry Service Project}

PROJECT:

Long-range transport of air pollutants

RESPONSIBILITY CENTRE:

Northern Forest Research Centre

CO-OPERATORS :

Manitoba Department of Northern Affairs and Environment

DURATION :

Long-term.

MAJOR OBJECTIVES:

1. To provide information to federal and provincial policy planners on the extent and impact of long-range transport of air pollutants in order to define national and regional objectives for air quality.

2. To provide information to federal and provincial agencies on the environmental impact of nuclear development within the region with particular respect to operation and decommissioning.

BENEFITS ON COMPLETION:

Major benefits will be the development of national and regional air-quality standards as related to the long-range transport of air pollutants (heavy metals and sulphur gases) and radionuclides standards as related to the operation and decommissioning of the uranium mining and milling industry. 
HIGHLIGHTS OF ACCOMPLISHMENTS TO DATE:

A network of permanent biomonitoring sites has been established around major point emitters to examine local and medium-range transport of air pollutants (heavy metals and sulphur gases) and their impact on forest vegetation and soils. New and improved methodology has been developed to monitor the distribution and impact of air pollutants on forest systems. Studies have been undertaken to determine the effect of major point emitters on rainfall quality. Studies of simulated acid rain on native vegetation are now underway.

Extensive sampling of native vegetation and soils has been undertaken to determine the movement of radionuclides around abandoned uranium mining and milling operations. An analytical facility to carry out analysis of radionuclides in vegetation, soils and water has been established at NoFRC.

CONTACT :

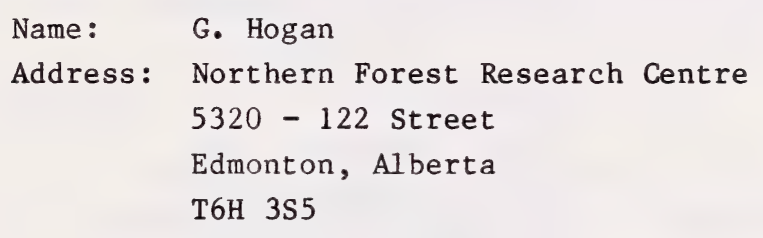

Phone: (403) 435-7210

FINANCES :

1982/83 expenditure

$\$ 205,000$

Projected expenditure for next five years Stable

LIST OF STUDIES IN CURRENT FISCAL YEAR:

Title

1. Impact of air pollutants from major regional sources on forest vegetation and sites.
Objectives

To determine the impact of airborne pollutants on terrestrial ecosystems, specifically vegetation and soils, for bench-
Investigator

G. Hogan

D. Maynard 
Title

2. Transport of radionuclides released from uranium mining and milling operations and their effects on forest vegetation and soils. marking and biomoni-

toring purposes; to

determine the rate and

extent of deposition

of major pollutants

from point emitters;

to determine the

extent to which local, medium- and long-range

transport of air pol-

lutants is degrading

forest ecosystems.

To develop methods for

M.J. Apps

the measurement of

G.D. Hogan

various uranium-series

radionuclides in

plants and soils; to

gather baseline data

on the distribution of

radionuclides in

forest vegetation and

soils; to study the

dynamics of cycling

on radionuclides and

associated elements

and their eventual

fate in terrestrial

ecosystems. 


\subsubsection{Canadian Forestry Service Project}

PROJECT:

Environmental impact assessments and peatland ecology

RESPONSIBILITY CENTRE:

Northern Forest Research Centre

CO-OPERATORS :

Environment Canada

Energy, Mines and Resources (Canada)

DURATION :

Environmental impact assessments as required; peatland ecology to be completed in 1988 .

MAJOR OBJECTIVES :

1. To assess the impacts of industrial developments on the terrestrial environment and to recommend measures for minimizing or mitigating the damaging impacts.

2. To provide expertise in the development of essential criteria for the design of major industrial developments and for the rehabilitation of disturbed areas.

3. To determine the ecology of peatland development within the region and to develop guidelines for peatland management and rehabilitation.

BENEFITS ON COMPLETION:

The major benefit of the environmental impact assessments will be a minimizing of environmental degradation following industrial development particularly on sensitive northern terrain and vegetation. An understanding of the ecology of 
peatland development will affect the potential harvesting of peat for energy production and the impact of its utilization on the environment.

HIGHLIGHTS OF ACCOMPLISHMENTS TO DATE:

Over the years considerable expertise and credibility has been developed in the area of environmental impact assessment and peatland ecology. Important contributions have been made in reviewing industrial development proposals (Mackenzie Valley Pipeline, Canadian Arctic Gas Pipeline, Foothills Pipeline, etc.) and in formulating guidelines for environmental safety as a result of such developments. Several natural resource inventory surveys have been carried out in connection with the proposed estabishment of national parks. Expertise is also being provided to determine the ecoregions of Canada. A major study is now underway to characterize peatland types on the basis of vegetation and physical and chemical properties of peat, and to develop guidelines for peatland management. Acquisition of data from peatlands of central Alberta and Manitoba is completed.

CONTACT :

Name: $\quad$ S.C. Zoltai

Address: Northern Forest Research Centre 5320 - 122 Street

Edmonton, Alberta

T6H 355

Phone: (403) 435-7210

FINANCES :

1982/83 expenditure

$\$ 165,000$

Projected expenditure for next five years

Stable 
LIST OF STUDIES IN CURRENT FISCAL YEAR:

Title

1. Environmental assessment and impact on developments of terrestrial environment.

2. Peatland development and ecology.
Objectives

To assess the impacts of industrial developments on the terrestrial environment and recommend measures for minimizing or mitigating the damaging impacts; to provide expertise in the development of essential criteria for the design of major industrial developments and for rehabilitation of disturbed areas.

To determine the ecology of peatland development within the region and develop guidelines for peatland management and rehabilitation.
Investigator

S.C. Zoltai

S.C. Zoltai

J.D. Johnson 


\subsubsection{Canadian Forestry Service Project}

PROJECT:

Forest hydrology and microclimate research

RESPONSIBILITY CENTRE:

Northern Forest Research Centre

CO-OPERATORS :

Alberta Forest Service

Alberta Environment

Inland Waters Directorate

Atmospheric Environment Service

Canadian Wildlife Service

DURATION :

Long-term

MAJOR OBJECTIVES:

1. To investigate and evaluate the effects of traditional and other forest clearing practices on soil moisture and microclimate.

2. To evaluate the effects of natural events (i.e., fire, insect and disease) and standard and other forest clearing activities on local water yield, regime and quality.

3. To provide forest management techniques to improve water yield from Alberta's Eastern Slope forests.

BENEFITS ON COMPLETION:

The major benefit will be improved forest watershed management techniques for Alberta's Eastern Slope forests. 
Three subbasins of the Marmot Experimental Watershed in the Kananaskis River Valley have been calibrated. A commercial harvest of the Cabin subbasin did not increase sediment in the stream but produced approximately $33 \mathrm{~mm}$ increase in annual water yield. The evaluation of the non-standard forest cutting practices designed specifically to optimize water yield or regime from Alberta's Eastern Slopes is underway. This evaluation is scheduled for completion by 1987-88. Over 2000 one-tree-height in diameter circular openings were cleared on the Twin subbasin. These clearings contain about twice as much snow at peak accumulation as the uncleared areas between. Streamflow from the Twin subbasin is being evaluated against that of the Middle subbasin, which was not harvested. These studies have fostered an active interest upon the part of Alberta Water Resources to conduct pilot-scale testing on a 200$300 \mathrm{Km}^{2}$ basin to demonstrate optimization of water yield by vegetation manipulation. Studies are also being planned to evaluate the impact of standard and non-standard forest clearing practices on microclimate and soil moisture, regeneration, establishment, production of fibre, rotation duration and recreational use of intensively managed forests.

Numerous clearings less than 0.4 ha were created in aspen forests on the Streeter Experimental Watershed in the northern Porcupine Hills. These were expected to retain snow on the upper slopes and to allow the meltwater to infiltrate the soil and appear as local spring flow. The results have shown a $48 \%$ increase in water yield since treatment.

Results from these watershed experiments are being used to verify a land-use hydrologic model. This model is to be one of the vehicles for transferring research findings into practical forest management prescriptions for water yield augmentation.

Results from other more theoretical studies such as the ones carried out at the James River snow study site are being used in the development of the land-use model. For instance, the wind speed measured near the ground surface on $1-2$ ha clearings in a $20 \mathrm{~m}$ tall lodgepole pine forest was one-tenth that measured above the canopy or in a 20ha clearing. These data indicate 
that transpiration, which can be measured directly using the numerical simulation of heat pulse velocity technique, can be reduced to a greater potential for water yield increase than can occur from forests commercially clearcut in larger blocks.

CONTACT :

Name: R.H. Swanson

Address: Northern Forest Research Centre

5320 - 122 Street

Edmonton, Alberta

T6H $3 \mathrm{~S} 5$

Phone: (403) 435-7210

FINANCES :

1982/83 expenditure

$\$ 260,000$

Projected expenditure for next five years

Stable

LIST OF STUDIES IN CURRENT FISCAL YEAR:

Title

1. Research co-ordination in the Alberta Watershed Research Program Marmot, Streeter, TriCreeks, Spring Creek Experiment Basins.
Objectives

To learn how to manage forested public lands for the protection of existing water supplies and the enhancement of future supply by alteration of regimes or yield through timber harvesting; to propose and test specific land management practices designed to increase annual water yield, retard flood peaks or improve on-site watershed condition; to evaluate and test
Investigator

R.H. Swanson 
-itle

Objectives

existing land manage-

ment practices with

respect to their

influence on the

hydrologic regime of

specific test areas.

2. Disposition of water in forest soils.

To develop from

Darcy's law and the continuity equation a mathematical model of two-dimensional transient unsaturated and saturated flow through porous media applicable under natural conditions; to incorporate the mathematical model as part of a physically based synthesis of the hydrologic cycle.

3. Measuring evapotranspiration of forests and clearings.

To evaluate transpiration of stands on experimental plots and

\section{Investigator}

G.R. Hillman

R.H. Swanson catchments for use in treatment evaluations; to develop relationships between microclimatic parameters, transpiration and evapotranspiration for use in hydrologic landuse models; to develop relationships describing evapotranspiration of residual stands and clearings in partial forest arrangements. 
Title

4. Vegetation manipulation hydrologic modelling.

5. Snow accumulation and ablation in forest openings.
Investigator

To develop vegetation

P.Y. Bernier

manipulation-

hydrologic models

G.R. Hillman

R.H. Swanson

applicable to the

Saskatchewan River

headwaters; to

incorporate the

results of other

studies dealing with

individual components

of the hydrologic

cycle into the watershed model.

To determine the influence of small

R.H. Swanson

forest openings on

snow accumulation

amounts, melt rates

and snow melt runoff

patterns. 


\subsubsection{Canadian Forestry Service Project}

PROJECT:

Climatic studies

RESPONSIBILITY CENTRE:

Northern Forest Research Centre

CO-OPERATORS :

Forintek Canada Corporation

St. Regis (Alberta) Ltd.

Canada Department of Energy, Mines and Resources

DURATION :

Long-term

MAJOR OBJECTIVES :

1. To provide forest resource managers with information to assess impact of climate on forest vegetation and soils, especially those associated with forest clearcut areas.

2. To determine the extent and degree of past short- and longterm climatic fluctuations and interrelationships between key climatic parameters and measures of forest biomass growth and productivity in selected regions of the boreal forest.

BENEFITS ON COMPLETION:

Major benefits include the rationalization of clearcutting block size as it relates to the negative impacts of climate on tree seedling growth, and the impact of climate fluctuations on the short- and long-term productivity of forests. 
HIGHLIGHTS OF ACCOMPLISHMENTS TO DATE:

Data collected in connection with the climate of clearcut areas and the climate/seedling growth study related to stand edge has been quality controlled and summarized for report publication. In 1979, a new study to determine the impact of climatic variation on forest biomass productivity was initiated. Two aspects of this study have been carried out through ENergy from the FORests (ENFOR) supported projects. One study was an extensive literature review on the impact of different climatic parameters on growth and yield of trees in the boreal zone, the report of which is currently under review for publishing. The second study in co-operation with Forintek Canada Corp. collected white spruce tree ring samples from 15 locations along two north-south transects through the boreal zone near $100.5^{\circ}$ and $115^{\circ}$ long. W.

A report on the analysed samples is under review for publishing. A report on the study "Impact of climatic variation on boreal forest biomass production" has been published.

CONTACT :

$\begin{array}{ll}\text { Name: } & \text { J.M. Powe } 11 \\ \text { Address: } & \text { Northern Forest Research Centre } \\ & 5320-122 \text { Street } \\ & \text { Edmonton, Alberta } \\ & \text { T6H } 3 \mathrm{~S} 5\end{array}$

Phone: (403) 435-7210

FINANCES :

$\begin{array}{lr}1982 / 83 \text { expenditure } & \$ 90,000 \\ \text { Projected expenditure for next five years } & \text { Stable }\end{array}$

LIST OF STUDIES IN CURRENT FISCAL YEAR:

Title

1. Impact of climatic variation on boreal forest biomass production.

\section{Objectives}

To assess impact of climate on forest vegetation and soils, especially those

\section{Investigator}

J.M. Powe11,

T. Singh 
associated with forest

clearcut areas; to

determine extent and

degree of past short-

and long-term climatic

fluctuations and

interrelationships

between key parameters

and measures of

biomass productivity

in selected regions of

the boreal forest. 


\subsubsection{Canadian Forestry Service Project}

PROJECT:

Ecological land classification of national parks

RESPONSIBILITY CENTRE:

Northern Forest Research Centre

CO-OPERATORS :

Parks Canada

Alberta Institute of Pedology

Canadian Wildlife Service

DURATION :

To be completed by March, 1984 .

MAJOR OBJECTIVES:

1. To provide a land, soil and vegetation inventory of Banff and Jasper national parks and an interpretation of the data for land-use planning and management within the parks.

2. To provide an ecological land classification of Kootenay, Glacier and Mount Revelstoke national parks and an interpretation of the data for land-use planning and management, integrating land, soil, vegetation, wildlife and aquatic resource components.

BENEFITS ON COMPLETION:

The major benefit will be improved land-use planning and management of mountain national parks by Parks Canada.

HIGHLIGHTS OF ACCOMPLISHMENTS TO DATE:

Soil survey of Waterton National Park has been completed and report published, in association with the Alberta Institute of 
Pedology. A land classification integrating soil and vegetation resources has been completed and reported for the Lake Louise area of Banff National Park.

The ecological land classification of Banff and Jasper national parks has been completed and the final reports (volumes I and II) published. Field work for the ecological land classification of Kootenay National Park was completed in 1982; Mount Revelstoke and Glacier national parks require about 20 days of additional summer field work to increase the intensity of field sampling. Report finalization for the three parks is scheduled for March 31, 1984.

CONTACT :

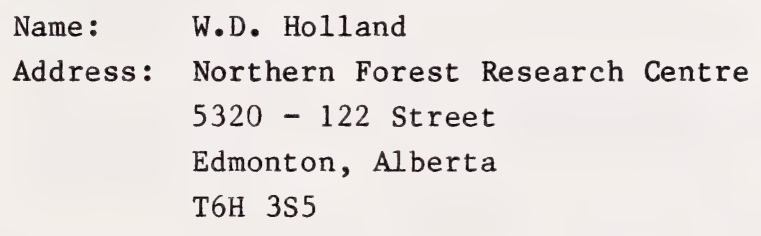

Phone: (403) 435-7210

FINANCES :

$1982 / 83$ expenditure

Projected expenditure for next five years
$\$ 165,000$

$\mathrm{Nil}$

LIST OF STUDIES IN CURRENT FISCAL YEAR:

\section{Title}

1. Land and vegetation resource inventory of Banff and Jasper national parks.

\section{Objectives}

To provide a land, soil and vegetation inventory of Banff and Jasper national parks and an interpretation of the data for land-use planning and management.

\section{Investigator}

W.D. Holland 
Title

2. Ecological land classification of national parks.
Objectives

To provide an ecologic- W.D. Holland

al land classification

of Kootenay, Glacier

and Mount Revelstoke

national parks and an

interpretation of data

for land-use planning

and management inter-

preting land, soil, vegetation, wildlife

and aquatic resources.
Investigator

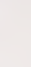




\subsubsection{Canadian Forestry Service Project}

PROJECT :

Remote sensing applications

RESPONSIBILITY CENTRE:

Northern Forest Research Centre

CO-OPERATORS :

Alberta Forest Service

Saskatchewan Forest Service

Manitoba Forest Service

Forest industries

Canada Department Indian Affairs and Northern Development (Yukon, N.W.T.)

DURATION :

Long-term

MAJOR OBJECTIVES :

1. To evaluate, develop and apply new remote sensing and interpretation techniques for forest inventories and environmental management purposes.

2. To develop improved forest management information systems and apply the data bases in simulation models to test various management strategies.

BENEFITS ON COMPLETION:

Improved remote sensing and interpretation techniques for forest inventories, forest management, forest protection and environmental management. 
HIGHLIGHTS OF ACCOMPLISHMENTS TO DATE:

Over a number of years, areas of expertise and credibility have been built up in large-scale photo sampling, satellite image classification, aerial photography, mapping, computer applications and forest inventory sampling designs.

An effective, comparatively low-cost, large-scale photo sampling system with precision radar altimeter recording has been developed in prototype form for sample plot extensions in forest stand, regeneration and damage assessments. Computer programs for large-scale photo sampling and ground plot compilation into average stand and stock tables have been developed for use in the region.

An unsupervised classifier for digital Landsat imagery was made operational on the PDP-11/60 computer.

A computerized Mapping and Analysis of Resources System has been installed and made operational at the NoFRC.

A multistage sampling design applicable to forest appraisals which utilizes measurements from ground sampling, aerial photography and satellite imagery has been developed and tested in the boreal and subalpine forest regions.

Aerial photography of forest regeneration was obtained and analysed in co-operation with Abitibi-Price Ltd.

In co-operation with the Alberta Forest Service and the Forest Insect Disease Survey (NoFRC), color aerial photographs were obtained on which mountain pine beetle infestations will be located and mapped.

CONTACT:

Name: W. Moore

Address: Northern Forest Research Centre

5320 - 122 Street

Edmonton, Alberta

T6H 3S5

Phone: (403) 435-7210 
FINANCES :

1982/83 expenditure

$\$ 105,000$

Projected expenditure for next five years

Stable

LIST OF STUDIES IN CURRENT FISCAL YEAR:

Title

1. Remote sensing and technical advisory services.
Objectives

To evaluate, develop and apply new remote sensing and interpretation techniques for forest inventories and environmental management purposes; to develop improved forest management information systems and apply the data bases in simulation models to test various management strategies; to provide advisory services in survey design, interpretation methods and analyses as required.

2. Development and application of largescale photo and image analysis techniques to forestry.
To utilize new techniques and apply appropriate sampling designs in the application of largescale photography in acquiring resource inventory data; to assess and apply image analysis techniques in the interpretation and classification of forest resources; to
Investigator

W.C. Moore
R.J. Hall 
provide advisory

services in the

aquisition, uses and

analyses of remote

sensing imagery, in

survey design,

interpretation methods

and analysis. 


\subsubsection{Canadian Forestry Service Project}

PROJECT :

Resource opportunities and policy guidelines

RESPONSIBILITY CENTRE:

Northern Forest Research Centre

CO-OPERATORS :

Alberta Forest Service

Saskatchewan Forest Service

Manitoba Forest Service

Canada Department of Northern Development and Indian Affairs (N.W.T.)

DURATION :

Long-term

MAJOR OBJECTIVES :

1. To provide socio-economic information to regional forestry programs for rational policy formulation and program development.

2. To provide economic statistics and guidelines on costs and benefits, concerning the forest resource, impacts of forest management, marketing, and related socio-economic data.

BENEFITS ON COMPLETION:

This is an on-going project; short-term benefits include improved forest policies and forest management, and enhanced socioeconomic benefits.

HIGHLIGHTS OF ACCOMPLISHMENTS TO DATE:

Between 1978 and 1981 major forest industry surveys were updated in Alberta, Saskatchewan, Manitoba and the Northwest Territories. 
An information report has been prepared for Alberta and information reports for the other jurisdictions are under preparation. These comprehensive reports provide detailed information on the forest industry in the region and should lead to an effective analysis of the resource and ultimately to improved forest management and utilization. Summary versions of these reports were also prepared in the Forestry Report series. Directories of the wood-using industries in the three Prairie provinces and the Northwest Territories have also been prepared.

Comprehensive analyses of the forest industries were timely and have been most useful in the preparation of concept and discussion papers leading to the eventual signing of Forestry Development Agreements.

A computerized economic data base has been completed and is functional. An ENFOR Contract was supervised and a forest management note, "Harvesting of aspen biomass by dika side cutter", is under preparation.

CONTACT:

Name: $\quad$ D. Boylen

Address: Northern Forest Research Centre 5320 - 122 Street

Edmonton, Alberta

T6H 3S5

Phone: (403) 435-7210

FINANCES :

1982/83 expenditure $\$ 185,000$

Projected expenditure for next five years

Stable 
LIST OF STUDIES IN CURRENT FISCAL YEAR:

Title

1. An assessment of the forest-based economy of the Prairie provinces.
Objectives

To provide socioeconomic information to regional forestry programs for national policy formulation and program development; to provide economic statistics and guidelines on costs and benefits concerning the forest resource, impacts of forest management, marketing and related socioeconomic data.
Investigator

W. Ondro

T. Will1iamson 


\subsubsection{Canadian Forestry Service Project}

PROJECT:

Forest resource data

RESPONSIBILITY CENTRE:

Northern Forest Research Centre

CO-OPERATORS :

Alberta Forest Service

Saskatchewan Forest Service

Manitoba Forest Service

Canada Department Indian Affairs and Northern Development (N.W.T.)

DURATION :

Long-term

MAJOR OBJECTIVES:

1. To develop, operate and maintain a computerized system for compilation and analysis of appropriate forestry statistics to satisfy regional and national requirements.

2. To report at regular intervals on the changes in growing stock as a result of disasters, harvesting, silviculture, etc.

3. To contribute to the development of improved resource management guidelines by examining and testing simulation models based on regional research and operational data.

BENEFITS ON COMPLETION:

Up-to-date statistics for the region on inventory, depletions as a result of fire, harvesting and insect and disease losses; forest management statistics on silviculture treatments such as renewal and stand tending; and related statistics which will serve as a basis for CFS program planning. 
HIGHLIGHTS OF ACCOMPLISHMENTS TO DATE:

This is a regional project that forms part of the Canadian Forest Resource Data Program; this program is being co-ordinated across the country by the CFS Forest Statistics and Systems Branch (FSSB) located at the Petawawa National Forest Institute. Regional data have been collected for inclusion in national reports on forest inventories, seed collection areas and nursery facilities. Silviculture statistics for Canada were collected and analysed at NoFRC for the five-year period 1975-1980; a report summarizing the data has been published. Other subjects of interest to policy and decision makers including inventory depletions as a result of harvesting, fire, insect and disease losses will be addressed in the near future. In addition to the maintenance of a computerized system for the compilation and analysis of regional forestry statistics, periodic reports will be prepared and distributed and regional simulation models will be developed and tested to provide statistical forecast trends.

CONTACT:

Name: $\quad$ P.J. Golec

Address: Northern Forest Research Centre

5320 - 122 Street

Edmonton, Alberta

T6H $3 \mathrm{~S} 5$

Phone: (403) 435-7210

FINANCES :

1982/83 expenditure

$\$ 30,000$

Projected expenditure for next five years Stable

LIST OF STUDIES IN CURRENT FISCAL YEAR:

\section{Title}

1. Forest resource and operations statistics in Prairie provinces and NWT.

\section{Objectives}

To develop, operate and maintain a computerized system for compilation and analysis of appropriate
Investigator

P.J. Golec 


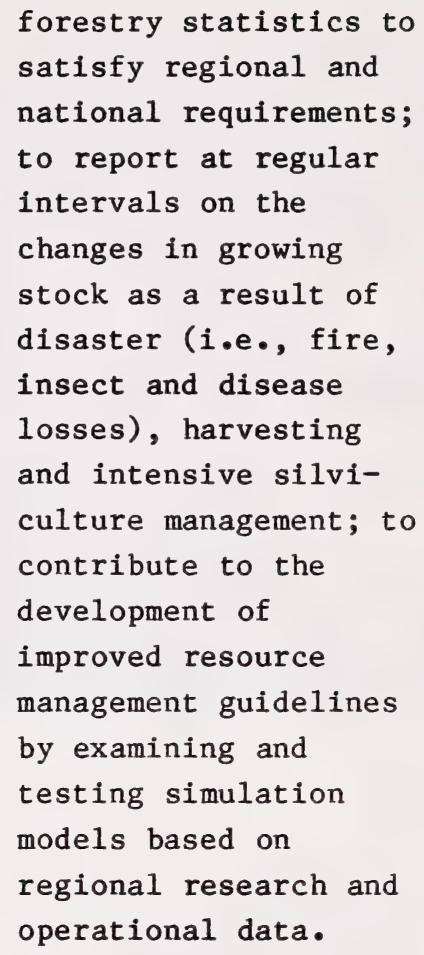




\subsubsection{Canadian Forestry Service Projects}

PROJECT:

Forest biomass as an energy source

RESPONSIBILITY CENTRE:

Northern Forest Research Centre

CO-OPERATORS :

Canada Department of Energy, Mines and Resources

ENFOR (ENergy from the FORest) contractors

DURATION :

Termination date, 1986

MAJOR OBJECTIVES :

1. To develop and test biomass prediction equations for regional tree species and lesser vegetation and demonstrate their integration with resource inventory programs.

2. To investigate the impact of biomass removal on site quality, nutrient status, silvicultural option and long-term productivity on selected sites in the Prairie provinces.

3. To determine production and delivery costs of biomass under various operating conditions and to provide a basis for evaluating the feasibility of using various forms of energy •

4. To develop and operate a computerized biomass data bank and information retrieval system to provide for more effective use of information and technology transfer. 
BENEFITS ON COMPLETION:

Major benefits include the ability to transform traditional forest inventories into biomass inventories; the development of methods of harvesting biomass for the production of energy or other uses of wood such as cattle feed, methanol, etc.; an assessment as to the effects of complete biomass removal on site quality and long-term site productivity.

HIGHLIGHTS OF ACCOMPLISHMENTS TO DATE:

The Canadian Forestry Service (CFS) is the lead agency in administering the federal Energy from the Forest Production Committee program. The Northern Forest Research Centre projects are an integral part of the National CFS program to assess the potential of biomass as an alternate energy source. In addition to a number of completed or on-going contracts listed below, some of the contract data has been worked on in-house or through service contracts to develop biomass prediction equations or specific gravity determinations for the region.

PROJECT

Biomass volume and yield tables

Line intersect sampling of forest fuels

Crop density and growth rates of woody plants

Tree biomass prediction equations for Prairies

Stand growth model for aspen

Computer mapping and demonstration of biomass inventory system

Climate biomass and tree ring analysis

Cimate and tree growth literature survey

Harvesting and chipping aspen

Nutrient relationships for aspen forests

Integrated harvesting and processing for poplar wood products and energy $\underline{\text { STATUS }}$

Report published

Report under review

Report published

Report published

Contractor's report available

System operational

Report under review

Report under review

Contractor's report available

Field work completed, analyses underway

Contractor's report available 
CONTACT :

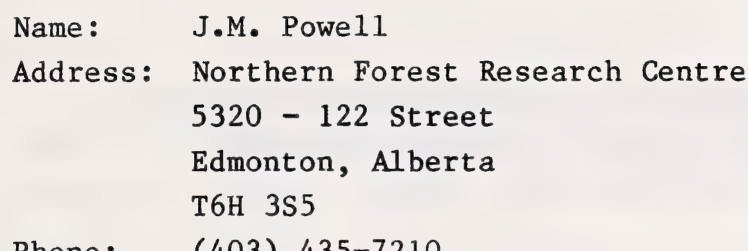

Phone: (403) 435-7210

FINANCES :

1982/83 expenditure

$\$ 330,000$

Projected expenditure for next three years Decrease

LIST OF STUDIES IN CURRENT FISCAL YEAR:

Title

1. An assessment of the energy potential of forest biomass in the Prairie provinces and N.W.T.

2. Development of integrated biomass equations for western and northern regions.
Objectives

To investigate the impact of biomass on site quality, nutrient status, silvicultural option and long-term site productivity on selected sites; to determine production and delivery costs of biomass under various operation conditions and to provide a basis for evaluating the feasibility of using various forms of biomass for energy.

To develop and test biomass prediction equations for regional tree species and lesser vegetation and demonstrate their integration with resource inventory programs.
Investigator

J.M. Powe11
T. Singh 
3. DIRECTORY OF ACTIVE RESEARCH PROJECTS AND STUDIES BY VARIOUS AGENCIES

3.4 Procter and Gamble Cellulose Ltd. 


\subsection{Procter \& Gamble Cellulose Ltd.}

CONTACT:

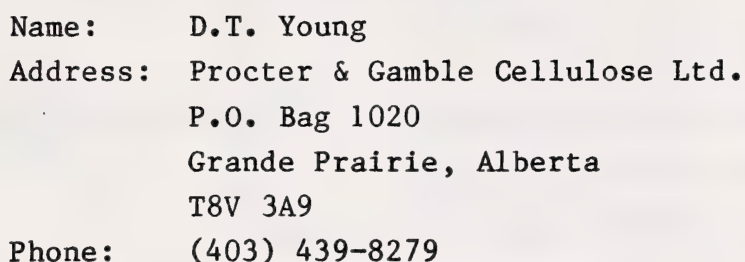

LIST OF STUDIES IN CURRENT FISCAL YEAR:

Title

1. Nitrogen fertilization study (70-year-old st and).

2. Progeny test establishment.

3. White spruce flowering.

4. White spruce plus tree selection.

5. Stocking standards.
Objectives

To increase diameter growth in dense lodgepole pine stands approaching maturity.

To plant 400 families grown from plus tree seed to determine the genetic merit of each selection.

To test the effect of geographic movement on the flowering of white spruce.

To obtain 120 white spruce plus trees for testing.

To determine the proper stocking level and species mixture to meet company objectives related to rotation age, volume and individual tree size.
Investigator

D.T. Young,

J. Edwards

D.T. Young, J. Edwards

D.T. Young, J. Edwards J. Edwards D.T. Young, J. Edwards 
Title

6. Wet site test.

7. Seed movement.

8. White spruce release trials.

9. Plant community descriptions.

10. Lodgepole pine fertilization (bulk seed orchard).
Objectives

Investigator

To determine proper

D.T. Young,

species for reforesta-

J. Edwards

tion of poorly drained

sites.

To identify superior

D.T Young,

seed cones and test

J. Edwards

the effect of moving

seed more than 50

miles or 500 feet in

elevation.

To determine growth

response of white

D.T. Young,

J. Edwards

spruce to release from

mature aspen stand; to

determine the effect-

iveness of Velpar

gridballs as a chemi-

cal release agent.

To consolidate avail-

able information on

plant communities

found in the southern

part of the Forest

Management Agreement

(FMA) and field test

the manual to deter-

mine its applicability

for other locations

within FMA areas.

To monitor the survival of container

D.T. Young,

J. Edwards

J. Edwards

plantation established

in 1980 , test the

effectiveness of $\mathrm{N}-\mathrm{P}-\mathrm{S}$

fertilizers on height

growth and observe the 
Title

11. Fertilization of lodgepole pine seedlings.

12. Spruce container seedling trials on wet sites.

13. Spruce seedling fertilization.

14. Braecke heap scarifier simulation study.

15. Root regeneration potential.
Objectives

$\underline{\text { Investigator }}$

effect of fertilizer

on flowering of seed-

lings.

To enhance growth of

D.T. Young,

seedlings to minimize

J. Edwards

time required to reach

6-8 foot height.

To compare the

D.T. Young,

survival and growth of

J. Edwards

white spruce and black

spruce seedlings grown

in flat peat plugs and

Spencer-Lemaire

containers planted on

wet sites.

To increase survival

D.T. Young,

and growth of white

J. Edwards

spruce container stock

in cold wet soils by

applying phosphorous

fertilizer.

To increase seedling

D.T. Young, growth and range of

sites potentially

suitable to Braecke

scarification by

forming soil heaps

manual1y.

To determine whether

D.T. Young,

planting stock over-

J. Edwards wintered on the lease

areas has the same

growth potential as

stock overwintered at

Pine Ridge Forest

Nursery. 
Title

16. Poplar biomass.
Objectives

To obtain and test the performance of various hybrid poplar clones for biomass production.

\section{Investigator}

D.T. Young,

J. Edwards 
3. DIRECTORY OF ACTIVE RESEARCH PROJECTS

AND STUDIES BY VARIOUS AGENCIES

3.5 Blue Ridge Lumber (1981) Ltd. 


\subsection{Blue Ridge Lumber (1981) Ltd.}

CONTACT:

$\begin{array}{ll}\text { Name: } & \text { D. D'Amico } \\ \text { Address: } & \text { Blue Ridge Lumber Ltd. } \\ & \text { P.0. Box } 1079 \\ & 5210 \text { Railway Avenue } \\ & \text { Whitecourt, Alberta } \\ & \text { TOE 2LO }\end{array}$

Phone: (403) 648-3733

LIST OF STUDIES IN CURRENT FISCAL YEAR:

\section{Title}

1. Monitoring plots in areas with different scarification treatment.

2. Progeny or family test field trials.
Objectives

To determine the effect of scarification on the establishment, survival and growth of seedlings and to quantify the rate of ingress.

To field-test and evaluate progenies of plus trees in terms of survival, hardiness and juvenile growth.

3. Scotch pine provenance

\footnotetext{
trial. available seed source to be planted as a commercial timber source.

4. Species trial - 1 .

To test and evaluate

Siberian larch as a

potential timber-

producing species.
}

To determine the best
D. D'Amico

\section{Investigator}

D. D'Amico 
Title

5. Species trial - 2 .

6. Ingress studies.

7. Spacing/Nelder trial.
To test and evaluate growth performance of black spruce, tamarack and Siberian larch.

To determine the rate and duration of ingress and identify the proper time to conduct regeneration surveys .

To determine the effect of spacing on subsequent growth and wood quality of lodgepole pine.

\section{Investigator}

D. D'Amico

D. D'Amico

D. D'Amico 
4. APPENDICES 


\subsection{Staff Involved in Forestry Program at the University of Alberta}

Dean

Dr. Roy R.T. Berg, professor

Animal science

Associate Dean - Forestry

Prof. Peter J. Murphy, professor

Forest policy, forest fire science

Department of Forest Science

Dr. Lars Bach, associate academic staff

Alberta Research Council (joint with Agricultural Engineering)

Wood science and forest products

Dr. James A. Beck, Jr., professor

Forest resources management and economics

Prof. Cal D. Bricker, sessional lecturer

Alberta remote sensing

Dr. James R. Butler, associate professor

Wildland recreation, environmental interpretation

Dr. John D. Campbe11, associate academic staff

Alberta Research Council

Paleoclimatology, dendrochronology

Dr. Bruce P. Dancik, associate professor

Dendrology, forest genetics

Dr. L. Florence, assistant professor

Forest genetics

Dr. D. R. Govindaraju, research associate (NSERC)

Forest genetics

Mr. A. D. Hall, associate academic staff

Canadian Forestry Association

Forest policy, forest history

Dr. Jack D. Heidt, associate professor

Forest measurements, resource economics

Dr. A. Kare Hellum, professor

Silviculture, seed biology

Dr. Kenneth 0. Higginbotham, associate professor

Forest ecology, tree physiology 
Dr. Yasuyuki Hiratsuka, associate academic staff

Canadian Forestry Service

Forest pathology (joint with Plant Science)

Mr. John N. King, research associate (NSERC) (through December, 1982) Forest genetics

Prof. Archie G. Landals, sessional lecturer

Alberta Recreation and Parks

Wildland recreation

Prof. Peter J. Murphy, chairman, associate dean - Forestry Forest policy, forest fire science

Prof. Barrie L. Phillips, assistant professor

Forest resource management

Mr. Howard G. Pratley, administrative professional officer Administration, spring camp director

Dr. Richard L. Rothwe11, associate professor

Forest hydrology, watershed management, wetland hydrology

Dr. Robert H. Swanson, associate academic staff

Canadian Forestry Service

Forest hydrology, watershed management

Dr. Stephen J. Titus, associate professor

Forest biometrics, forest measurements

Dr. David G. Walker, research associate (NSERC)

Reclamation

Dr. Paul M. Woodard, associate professor

Forest fire science

Dr. Francis C. Yeh, associate academic staff

B.C. Ministry of Forests

Forest genetics

\section{Department of Agricultural Engineering}

Prof. A. Wayne Anderson, associate professor Systems analysis

Dr. Lars Bach, associate academic staff

Alberta Research Council (joint with Forest Science)

Wood science and forest products

Dr. B. Bains, research associate (NSERC)

Wood chemistry - wood quality

Prof. E. G. A. Grimmer, associate professor

Forest harvesting, transportation 
Dr. H. Paige Harrison, professor

Forest mechanization

Dr. Fenton V. Machardy, professor

Economics of mechanization, renewable resource energy

Dr. Michael M. Micko, associate professor

Wood science and technology, wood utilization

Dr. I. Wang, research associate (NSERC)

Wood science

Department of Animal Science

Dr. Robert J. Hudson, associate professor

Wildlife productivity and management

Department of Entomology

Dr. W. George Evans, professor

Forest entomology

Department of Plant Science

Dr. Arthur W. Bailey, professor

Range ecology, management

Dr. Peter Blenis, assistant professor

Forest pathology

Prof. R. Hugh Knowles, professor

Landscape architecture

Dr. Saul Zalik, professor

Plant physiology, biometrics

Department of Rural Economy

Dr. Michael R. Carroll, associate professor

Forest economics

Dr. Murray H. Hawkins, professor

Marketing, business management

Dr. Travis W. Manning, professor

Natural resource economics

Dr. William E Phillips, professor

Natural resource economics

Dr. Wolfgang M. Schultz, professor

Finance, production economics 
Dr. David S. Chanasyk, assistant professor Soil physics

Dr. Ted D. Cook, professor

Soil microbioloy, oil spill reclamation, rhizosphere studies

Dr. Peter Crown, associate professor

Remote sensing, soils classificaton

Dr. William B. McGill, professor

Soil biology, oil spill reclamation and organic matter turnover

Dr. Marvin K. Nyborg, professor

Soil conservation, soil fertility, oil spill reclamation

Dr. Steve Pawluk, professor

Remote sensing, soil genesis and classification

Dr. Donald J. Pluth, associate professor

Forest soils, land use and classification

Dr. James A. Robertson, professor

Soil chemistry, general soil science

\section{Staff in Other Facilities}

Dr. W. Ayer, professor, Chemistry

Metabolites of pathogens in forest trees

(with Dr. Y. Hiratsuka)

Dr. T. L. Burton, professor and chairman, Recreation

Administration

Recreation planning

Dr. R. P. Heron, professor, Recreation Administration

Heritage interpretation

Dr. E. L. Jackson, associate professor, Geography

Resource recreation

Dr. G.H. LaRoi, professor, Botany

Plant communities and forest ecology

Dr. H. T. Lewis, professor, Anthropology

Fire use by native people

Prof. J. Longworth, professor, Civil Engineering

Testing of wood structures 
Dr. K. Morgan, associate professor, Genetics

Population genetics of tree species

Dr. Frank Nargang, assistant professor, Genetics

Molecular genetics

Dr. M. A. Pickard, professor, Microbiology

Antifungal substances

Dr. C. Strobeck, associate professor and chairman, Genetics Population genetics of tree species

Dr. G. S. Swinnerton, associate professor, Recreation

Administration

Recreation resources

Dr. J. Toth, professor, Geology

Peatlands 


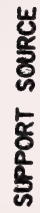

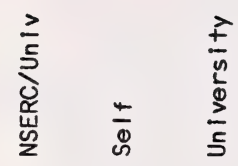

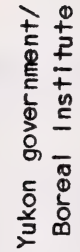

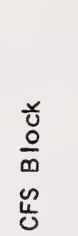

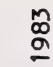

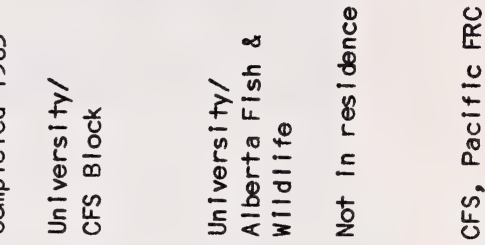

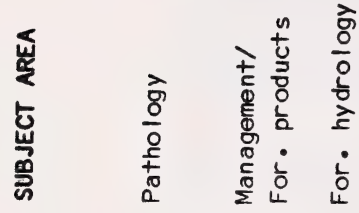

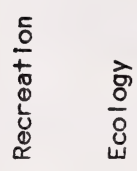

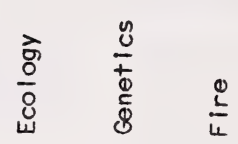

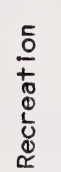

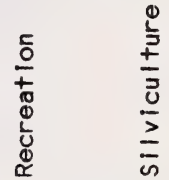

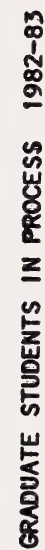

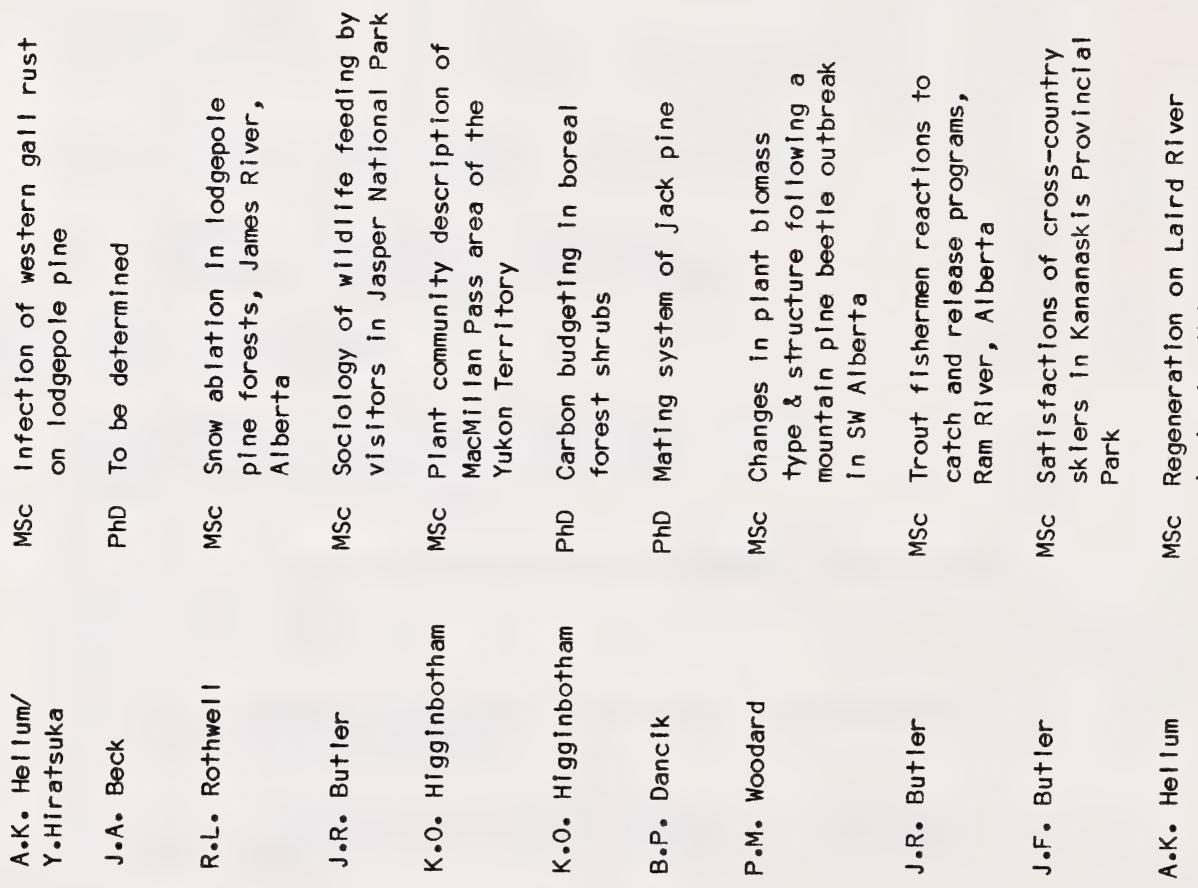

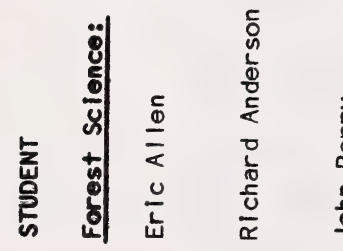

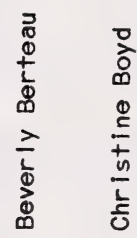

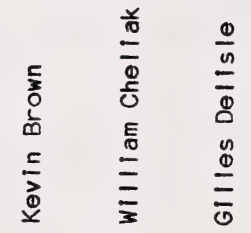

$\frac{1}{0}$
$\frac{0}{8}$
8
0
$\frac{0}{0}$
5

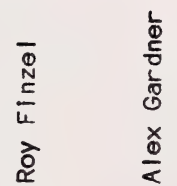




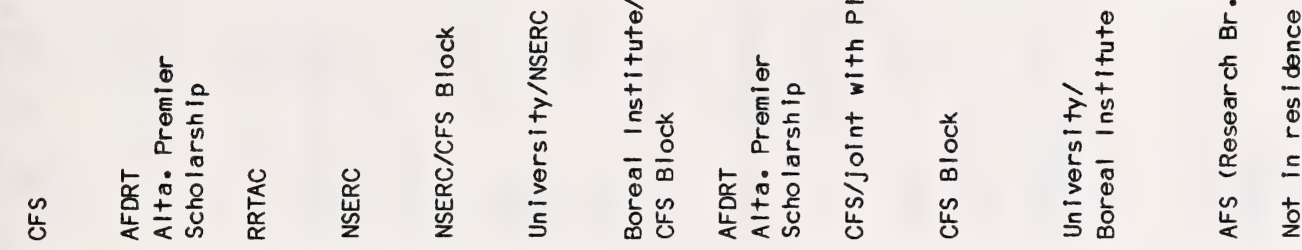

号

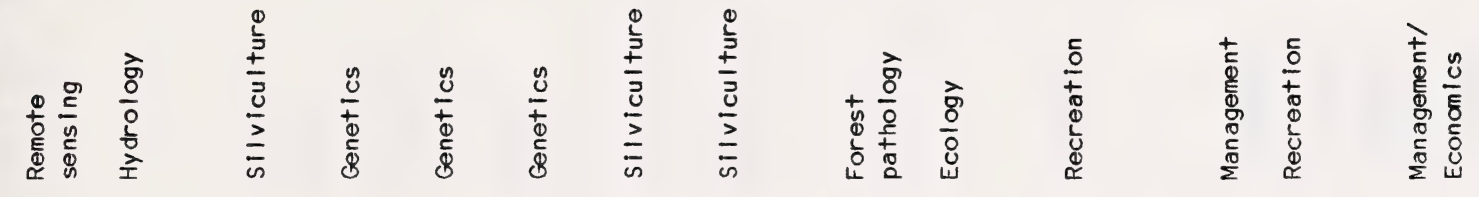

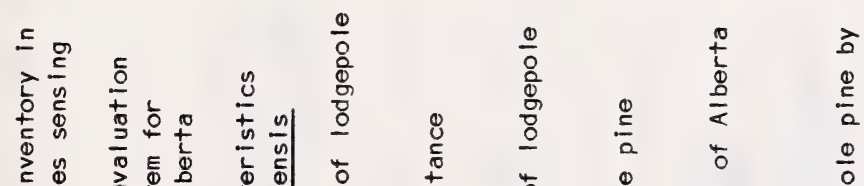

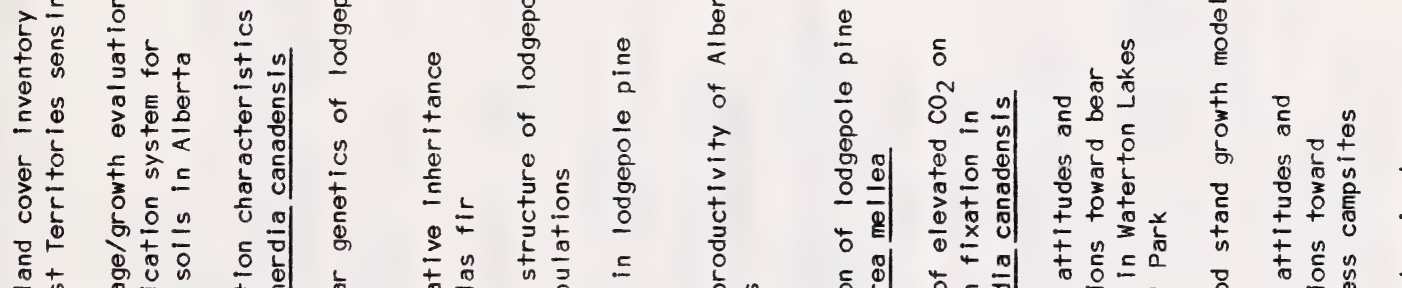

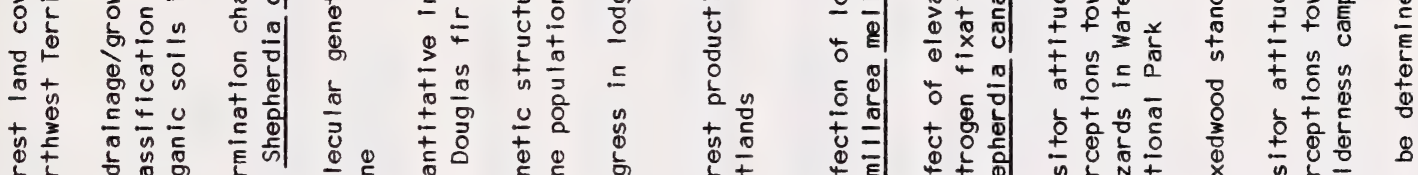

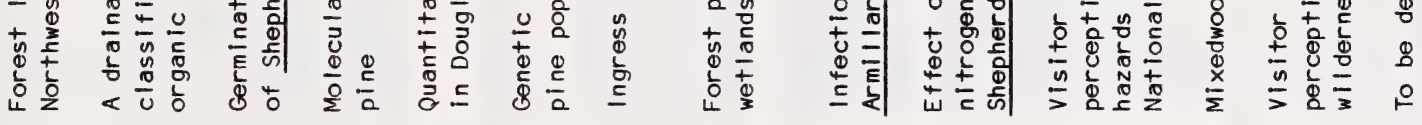

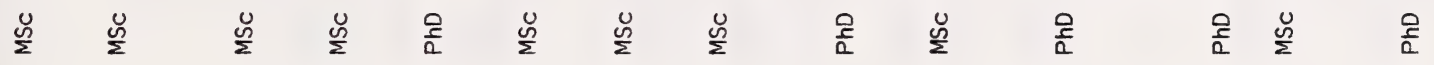

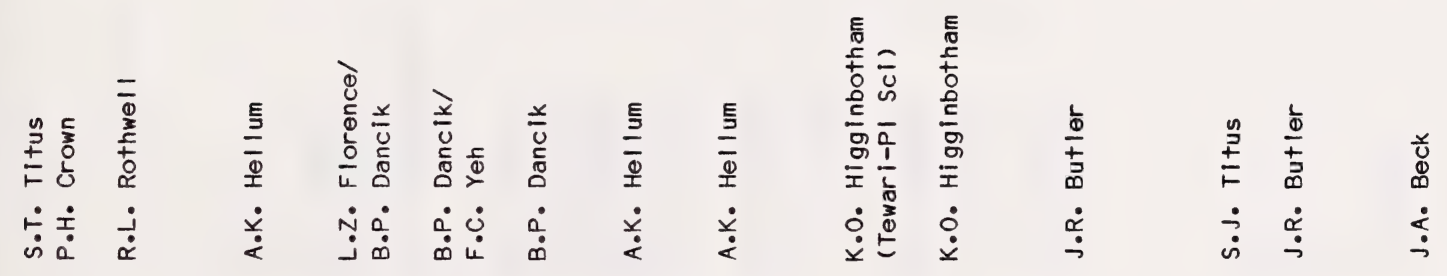

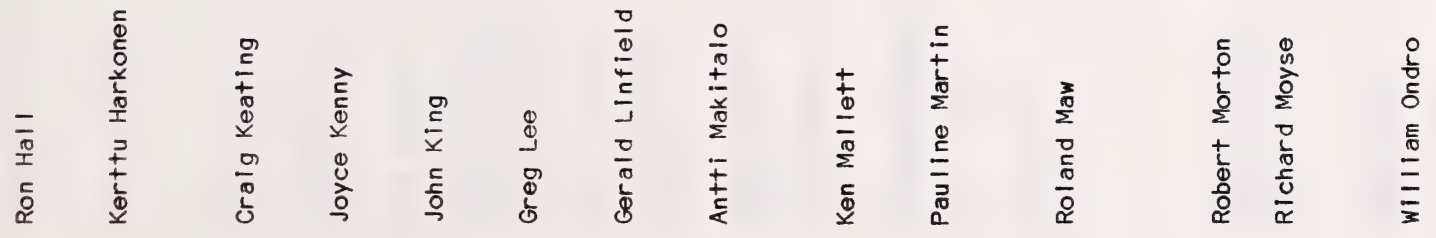




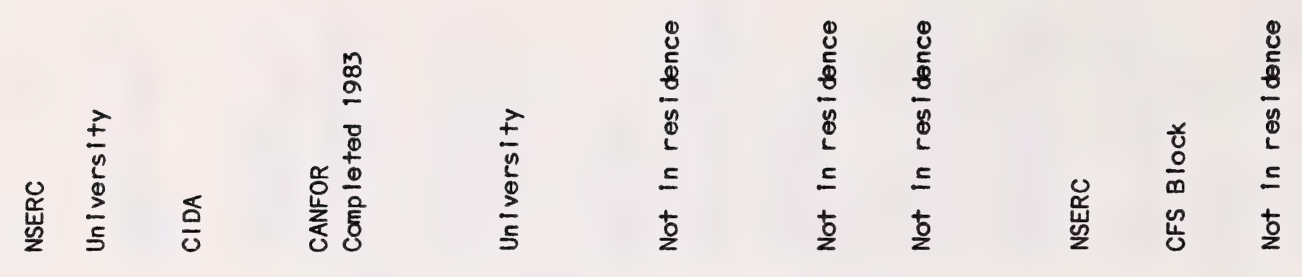

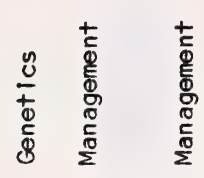

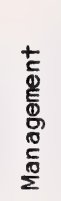

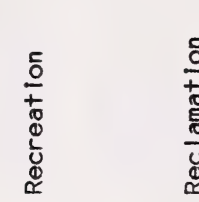

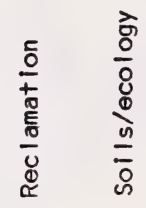

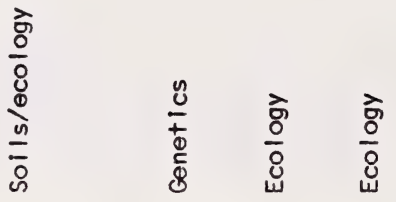
$\frac{5}{\frac{0}{0}}$

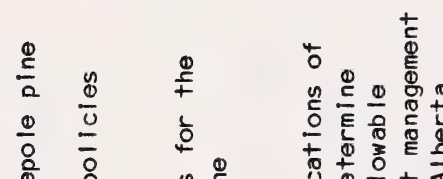

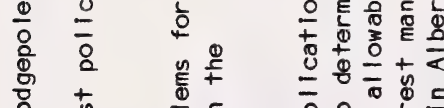

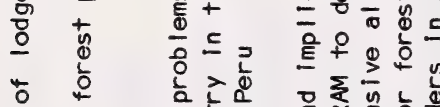

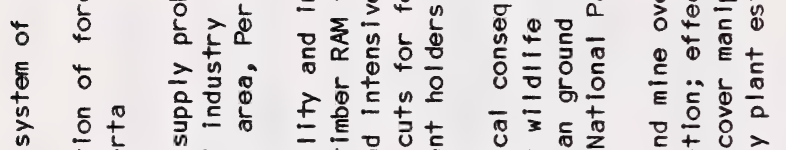

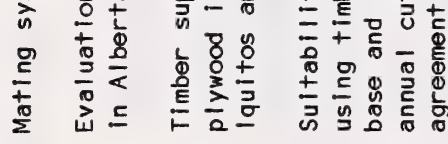

岕 옴

岕

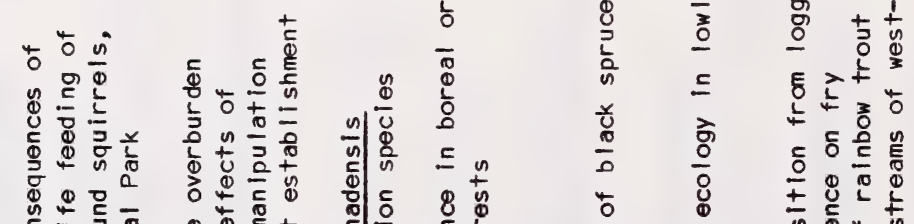

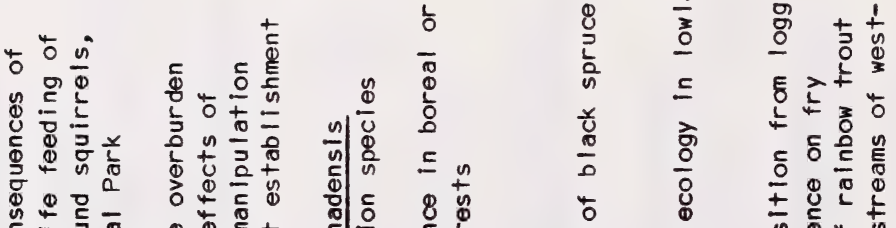

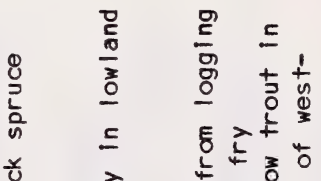

o 0

0
0
0

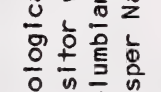

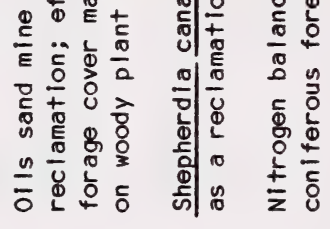

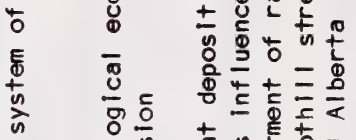

के $\frac{0}{2}$ 品

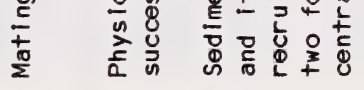

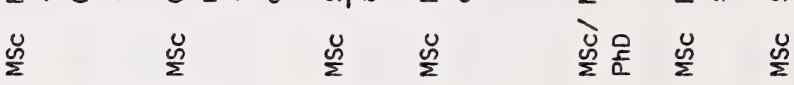

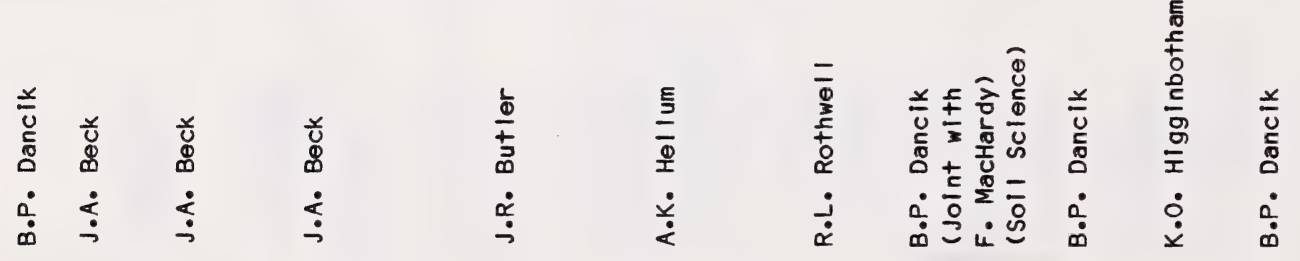

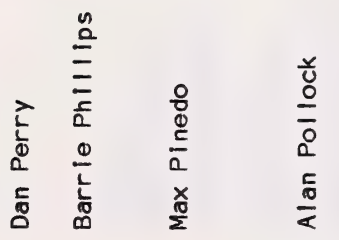

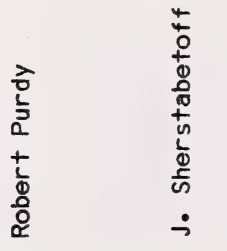

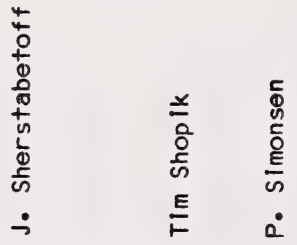

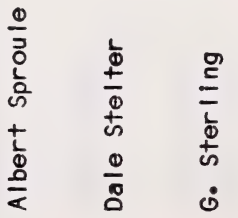




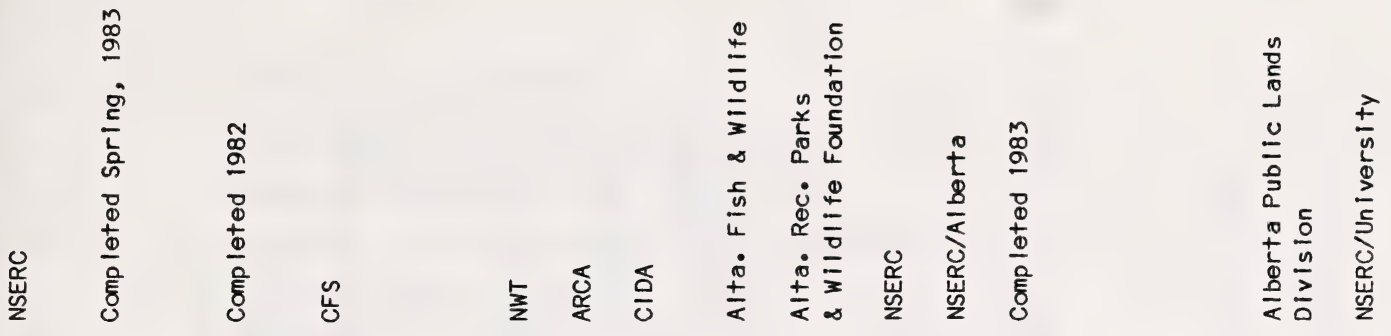

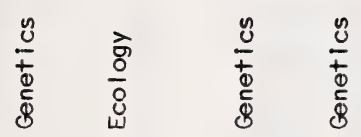

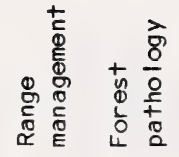

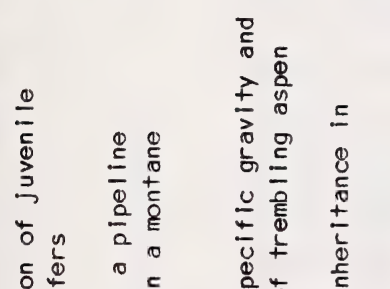

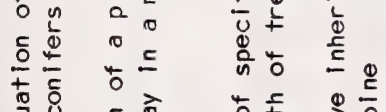

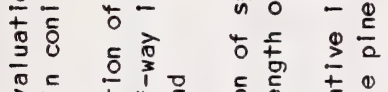

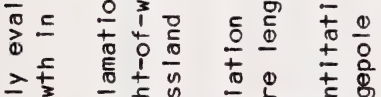

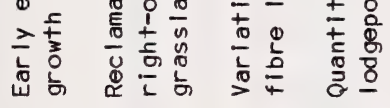

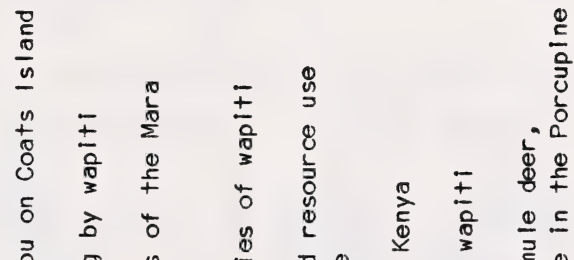

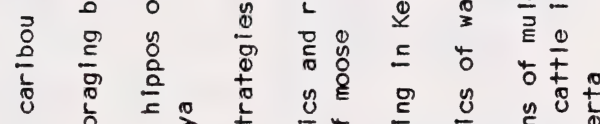

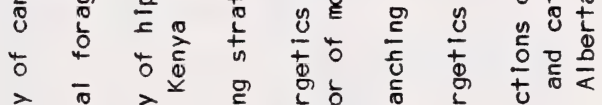

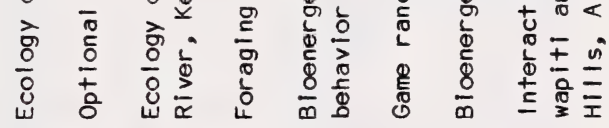

盛 宅

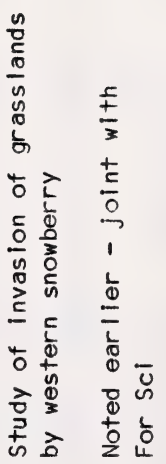

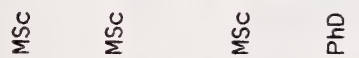

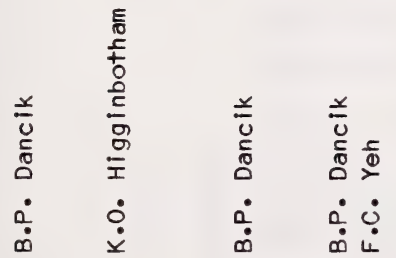

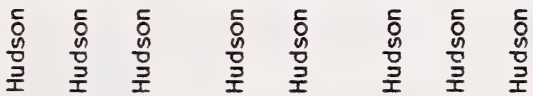

$\frac{\widehat{\sigma}}{\bar{\infty}}$

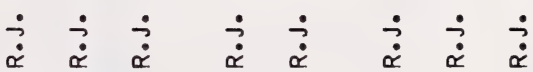

岕倠

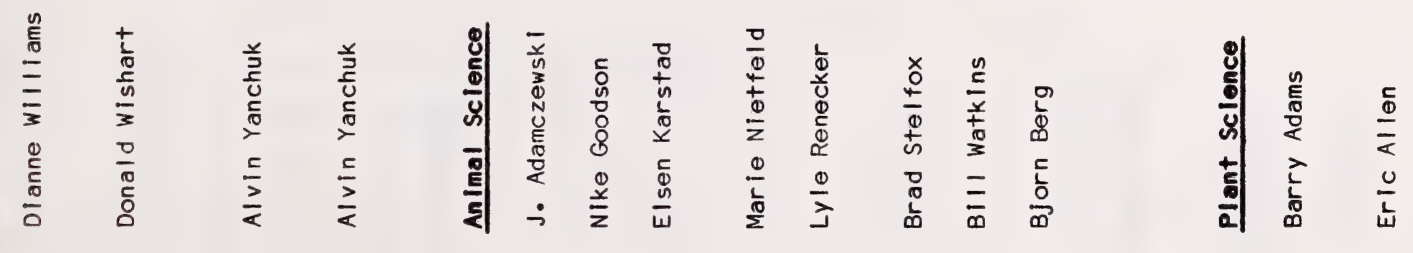




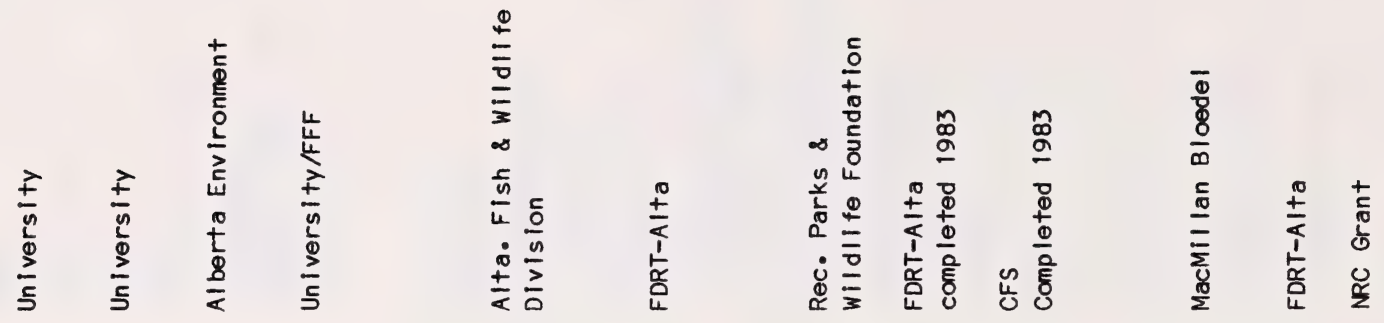

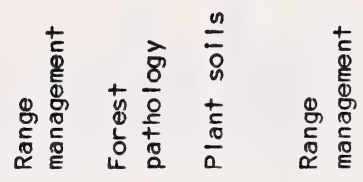

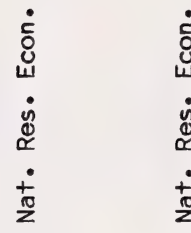

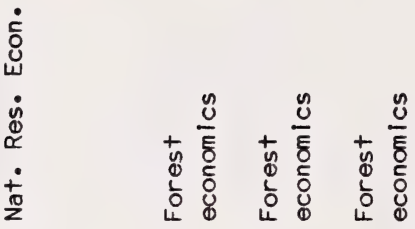

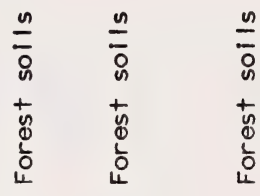

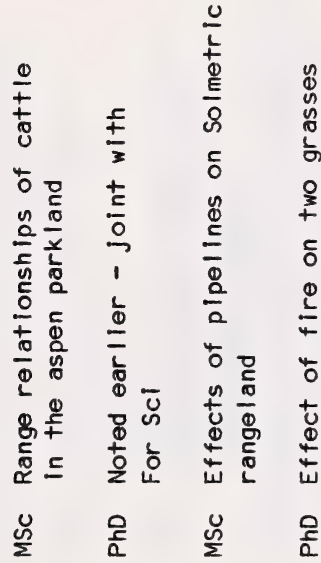

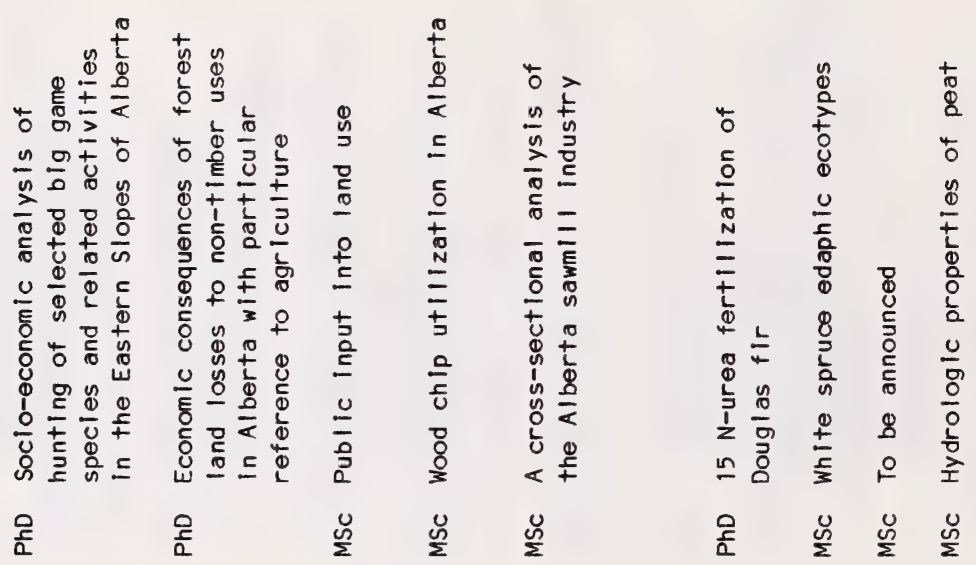

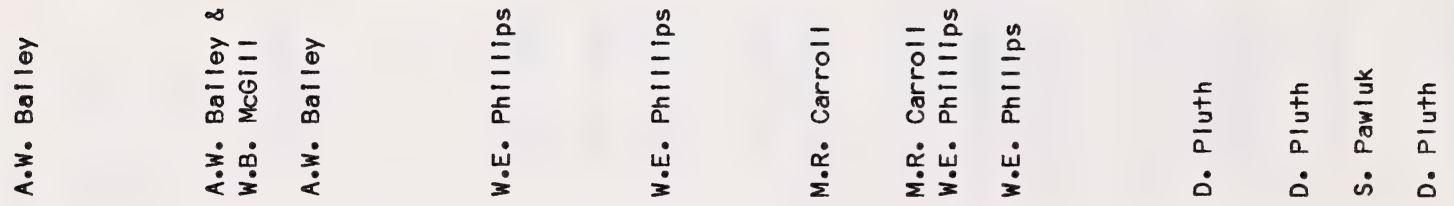

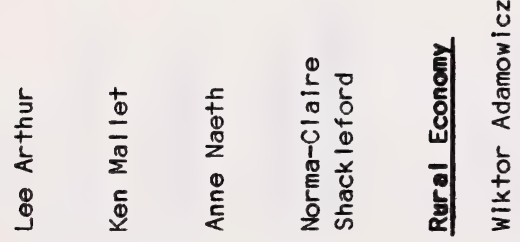

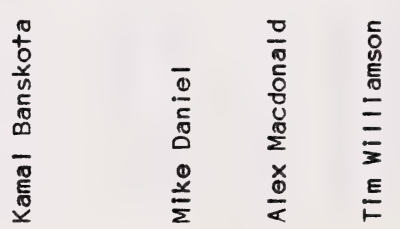

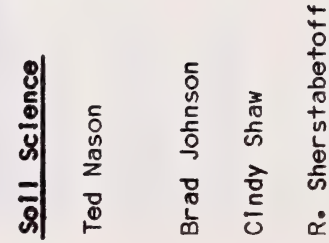




\subsection{INDEX OF RESEARCH SUBJECT AREAS}

Biomass (see Energy)

Biometrics (see Growth and Yield)

Climate Effects $18,43,106,107,123$

Diseases $11,18,19,25,43,52,76,82,83,84,101$

Drainage and Reclamation 9,11,23,98,99

Economics and Resource Data 12,16,120,121,122

Energy $119,120,121,124,125,126,131$

Environmental Pollutants 92,94,95,96,98,99

Fertilization (see Stand Management)

Fire $10,12,45,47,62,88,91,92,93,101$

Forest Industry $18,51,53,55,56,57$

Forest Products $51,52,53,55,56,57,59,60,61,62$

Genetics and Tree Improvement $8,20,24,38,73,74,75,126,128,129,131,133$

Growth and Yield

(Inc1. St and Modelling) 9,23,25, 34,69,71,80,83,119,126

Hydrology (Watershed) 32,49,101,102,104,105

Insects $12,43,76,79,80,82,83,101$

Inventory and Resource Allocations 9,24,51,112,114,119,120,121

Land Use $17,100,102,126$

Mensuration (see Growth and Yield)

Nurseries $20,25,27,43,64,65,66$

Physiology, Tree $9,25,64,66,67,122$

Plantation Establishment 23,25,34,68,128,131

Plantation Management $23,68,82,83,126,127,128,131$

Poplar Utilization $51,52,53,54,55,56,57,59,61,62$

Reclamation (see Drainage)

Recreation and Wildlife 9,10,12,23

Regeneration (Natura1) 34,131

Remote Sensing 112,114

Resource Allocation (see Inventory)

Resource Data (see Economics)

Seed Biology 8 
Site Classification

and Forest Soils $11,20,26,29,34,66,68,99,104,106,111,112,113,127$

Stand Management, Fertilization 41,69,71,72,127,128

Stand Management, Thinning 41,69,72,126

Watershed (see hydrology)

Wood Science 11,18 

